\title{
Geomechanical characterization of mud volcanoes using P-wave velocity datasets
}

DOI:

$10.1144 / S P 458.2$

\section{Document Version}

Accepted author manuscript

Link to publication record in Manchester Research Explorer

\section{Citation for published version (APA):}

Gulmammadov, R., Covey-Crump, S., \& Huuse, M. (2017). Geomechanical characterization of mud volcanoes using P-wave velocity datasets. Geological Society Special Publication, 458, 273-292.

https://doi.org/10.1144/SP458.2

\section{Published in:}

Geological Society Special Publication

\section{Citing this paper}

Please note that where the full-text provided on Manchester Research Explorer is the Author Accepted Manuscript or Proof version this may differ from the final Published version. If citing, it is advised that you check and use the publisher's definitive version.

\section{General rights}

Copyright and moral rights for the publications made accessible in the Research Explorer are retained by the authors and/or other copyright owners and it is a condition of accessing publications that users recognise and abide by the legal requirements associated with these rights.

\section{Takedown policy}

If you believe that this document breaches copyright please refer to the University of Manchester's Takedown Procedures [http://man.ac.uk/04Y6Bo] or contact uml.scholarlycommunications@manchester.ac.uk providing relevant details, so we can investigate your claim.

\section{OPEN ACCESS}


1 Geomechanical characterization of mud volcanoes using Pwave velocity datasets

\author{
RASHAD GULMAMMADOV, STEPHEN COVEY-CRUMP, MADS HUUSE \\ School of Earth and Environmental Sciences, University of Manchester, Manchester, M13 \\ 9PL, U.K. \\ *Corresponding author (e-mail: rashad.gulmammadov@alumni.manchester.ac.uk)
}

8 Abstract: Mud volcanoes occur in many petroliferous basins and are associated with

9 significant drilling hazards. To illustrate the type of information that can be extracted

10 from limited petrophysical datasets in such geomechanically complex settings, we use

11 P-wave velocity data to calculate mechanical properties and stresses on a 2D vertical

12 section across a mud volcano in the Azeri-Chirag-Guneshly field, South Caspian Basin.

13 We find (a) that the values of the properties and stresses calculated in this way have

14 realistic magnitudes, (b) that the calculated pore fluid pressures show spatial variations

15 around the mud volcano which potentially highlight areas of fluid recharging after the

16 most recent eruption, and (c) that the information obtained is sufficient to provide

17 helpful indications of the width of the drilling window. While calculations of this kind

18 may be readily improved with more sophisticated petrophysical datasets, the simplicity

19 of the approach we use makes it attractive for reconnaissance surveys designed to

20 identify targets worthy of further investigation in developing our understanding of mud

21 volcano geomechanics or which could be used to help formulate drilling strategies.

23 To date around 6500 mud volcanoes have been identified worldwide, both onshore and

24 offshore (Judd 2005). They are primarily developed where mudstone sequences are

25 overlain by thick and rapidly deposited sands from modern and Tertiary deltas, for

26 example, the Volga in the South Caspian Basin, the Baram in Borneo, the Niger in West

27 Africa, the Mississippi in the U.S.A., and the Mackenzie in Arctic Canada (Allen \& Allen

28 2013). Their occurrence is generally associated with an active tectonic setting, rapid

29 sedimentation and high rates of gas generation (Milkov 2000). 
As pathways for fluid release from deeply buried and overpressured sedimentary successions, mud volcanoes in petroliferous basins are important features to consider in reducing the risk and uncertainty within different parts of the Exploration \& Production cycle. Their feeder pipes may rupture the seal and allow hydrocarbon fluids and entrained sediment to migrate up through the sealing sequences (Cartwright et al. 2007; Hong et al. 2013). This does not necessarily imply total failure of the seal because it is the timing and efficiency of mud volcano eruptions relative to the timing of petroleum charging that defines the failure level of the seal (Cartwright et al. 2007). Indeed in many cases petroleum accumulations are discovered because of seal breach and the subsequent leaking of hydrocarbon rich fluids to the surface at the sites of mud volcanoes (Clarke \& Cleverly 1991). Nevertheless, the presence of mud volcanoes and the scale, geometry and activity of the plumbing systems beneath them are clearly important factors to consider when formulating strategies for field development and the siting of the facilities.

For these reasons, among others, mud volcanoes have been systematically studied worldwide to develop an understanding of (a) the controls on their internal structure and geomorphology (Hovland et al. 1997; Dimitrov 2002; Deville et al. 2003; Evans et al. 2007; Soto et al. 2011), (b) the structural controls on mud volcano locations (Roberts et al. 2011; Bonini 2013), (c) fluid/sediment flow under mud volcano complexes (Planke et al. 2003; Calvès et al. 2008), (d) the factors influencing the severity of mud volcano eruptions (Lerche \& Bagirov 1999; Kopf et al. 2009; Contet \& Uterseh 2015; Hill et al. 2015), and (e) controls on the geochemistry of the erupted fluids (Azzaro et al. 1993; Mazzini et al 2009; Bristow et al. 2000; Feseker et al. 2010; Oppo et al. 2014). In offshore areas, numerous multi-scale near-surface geological studies have been performed to mitigate the risks to seabed facilities that are associated with mud volcano activity and its accompanying hazardous phenomena, such as the presence of shallow gas, slope failure and pockmarks (Hill et al. 2015; Contet \& Unterseh 2015; Unterseh \& Contet 2015). Yet the extent to which drilling in such zones has to be avoided because of mud volcano related risks remains unclear.

59 Among the challenges posed by the complicated geology in and around mud volcanoes 60 is the prediction of local pore fluid pressures which has significant implications for 61 drilling (e.g. borehole blowouts and instability). Understanding these manifestations of 
62 localized fluid flow from a geomechanical perspective requires an analysis of the fluid

63 and pressure distribution, the deformation history, the distribution of fractures, and the

64 state of stress around the mud volcano. This, in turn, requires comprehensive

65 petrophysical datasets and sophisticated data analysis. However, within these

66 geomechanically complex areas there remains value in adopting a simpler

67 reconnaissance-type approach in order to identify targets for more detailed

68 investigation and key features that require a better understanding.

69 In this paper, we use P-wave velocity data available in the public domain to estimate the

70 mechanical properties and stresses on a 2D vertical section across a mud volcano

71 structure located in the Azeri part of the Azeri-Chirag-Guneshly (ACG) field, South

72 Caspian Basin (SCB). The aim of the study is to determine whether useful

73 geomechanical information can be extracted from such a limited dataset.

\section{Geological setting}

$75 \quad$ Regional geology

76 The South Caspian Basin, offshore Azerbaijan (Fig. 1a), is a deep Tertiary basin,

77 characterized by mobilized overpressured sediments that cause instability on the basin

78 margins and in deeper strata. The initiation of the basin corresponds to closure of the

79 Tethys Ocean as a result of Arabia-Eurasia convergence (Kopf et al. 2009; Morton et al.

80 2003). Subduction of the Arabian plate under Eurasia to the NNE generated an

81 accretionary prism during the Mesozoic/Early Tertiary. Following closure of Tethys

82 ( $\sim 20 \mathrm{Ma})$, continuing convergence and uplift to the north led to folding of a thick

83 Oligocene to Holocene sequence deposited in front of the previously active accretionary

84 prism (Jackson et al. 2002; Stewart \& Davies. 2006; Santos Betancor \& Soto 2015) (Fig.

85 1b). Along the northern margin of the basin, anticlinal structures developed within the

86 NW-SE trending Absheron-Balkhan deep-seated structural uplift, which is the offshore

87 extension of the Caucasus fold belt (Fig. 1a).

88 The sedimentary succession in the basin (Fig. 2) mainly comprises Cenozoic clastic

89 sediments deposited within three large delta systems: Kura from the west (sediments

90 from Lesser Caucasus), Amu Darya from the east (sediments from Balkhans) and Volga

91 from the north (sediments from Greater Caucasus and Urals) (Bredehoeft et al. 1988; 
92 Smith-Rouch 2006). These were deposited at remarkably high rates (up to $2.4 \mathrm{~km} \mathrm{Myr}^{-}$

$93{ }^{1}$ ) as the basin subsided, generating a sedimentary succession that is over $25 \mathrm{~km}$ thick

94 (Lerche \& Bagirov 1999). A cover sequence, up to $10 \mathrm{~km}$ thick, comprising sand-silt-

95 shale intercalations, was deposited during the Pliocene and Quaternary. The main

96 source rock for the extensive hydrocarbon reserves within the basin is the Maykop, a

97 kilometre thick sequence of organic-rich mudstones deposited during the Oligocene and

98 Early Miocene (Abrams et al. 1997; Jones et al. 1997). The main producing unit, both

99 onshore and offshore in the SCB, is the overlying Productive Series deposited during the

100 Late Miocene to Early Pliocene. This succession is composed of alternating, regionally

101 extensive, fluvio-deltaic sandstones, separated by laterally extensive lacustrine shales.

102 The lacustrine shales act as major pressure seals within the basin (Javanshir et al.

103 2015).

104 Within the South Caspian Basin rapid sediment burial has led to small geothermal

105 gradients $\left(13-18{ }^{\circ} \mathrm{C} \mathrm{km}^{-1}\right)$, setting the hydrocarbon generation depth at $5-10 \mathrm{~km}$ in the

106 western shelf and continental slope, and 6-14 km in the deep-water region (Guliyev et

107 al. 2011). The presence of low permeability seals coupled with the high rate of gas

108 generation, means that within the mudstone units there are abnormally high pore fluid

109 pressures. Pore fluid pressures in shales enclosing the regionally developed reservoirs

110 are estimated to exceed hydrostatic pressures by a factor of $\sim 1.8$, whereas in

111 sandstones within the basin the difference is a factor of $\sim 1.4$ (Bredehoeft et al. 1988).

112 The high rate of sedimentation and gas generation in the basin resulted in slow pore

113 fluid removal from the compacting mudstones during the burial and this has led to a

114 high level of under-compaction (Buryakovsky et al. 2001). These geological conditions,

115 coupled with the active tectonic regime, present a wide range of geological hazards for

116 oil and gas operations (Lerche \& Bagirov 1999). Among these are mud flows and gas

117 emissions that can damage rigs and production equipment, hydrate dissociation which

118 is hazardous for drilling activities, and the presence of submarine banks that are

119 dangerous to marine traffic. In addition to the natural hazards that are present on the

120 seabed and at shallow subsurface depths, significant challenges for drilling processes

121 are presented at greater depths by deep earthquakes and areas of large fluid

122 overpressure. 


\section{ACG field}

124 The ACG field complex is located within anticlinal structures on the northern boundary

125 of the South Caspian Basin at water depths of 95-425 m (Fig. 1a). The cores of these

126 anticlines contain mobile shales from the Maykop sequence - the depth to the top of this

127 sequence is $\sim 5 \mathrm{~km}$ in the ACG. Where this mobile shale has exploited zones of

128 weakness, mud volcanoes have formed resulting in the expulsion of mud and fluids,

129 including hydrocarbons, at the seabed. These mud volcanoes are developed within three

130 anticlinal culminations: Azeri, Chirag and Guneshly (Hill et al. 2015). Of these, the Chirag

131 mud volcano is the most extensively studied (e.g. Lerche \& Bagirov 1999; Stewart \&

132 Davies 2006).

133 The key geometric parameters and mechanical conditions of the Chirag mud volcano

134 are illustrated in Figure 3. This mud volcano is located at a water depth of $120 \mathrm{~m}$, and

135 contains several buried mud cones that are stacked vertically but share a common root

136 system (Stewart \& Davies 2006). The eruptive mud originates from the Maykop and is

137 composed primarily of montmorillonite clay with some volcanic ash (Buryakovsky et al.

138 2001; Evans et al. 2006). Geochemical evidence suggests that the fluids within the mud

139 volcano plumbing system also derive primarily from the Maykop (Mazzini et al. 2008;

140 Kopf et al. 2009) but with a contribution from the Productive Series (Lerche \& Bagirov

141 1999; Javanshir et al. 2015).

142 The pore fluid pressure gradients in the area are typically $0.0120 \mathrm{MPa} / \mathrm{m}$ (Buryakovsky

143 et al. 1995). Fluid overpressure in the area is generally associated with disequilibrium

144 (gravitational) compaction. The smectite-illite transformation occurs at temperatures of

$14575^{\circ}-150^{\circ} \mathrm{C}$, corresponding to depths of $>7 \mathrm{~km}$ (Feyzullayev \& Lerche 2009).

146 Based on the eruption statistics for onshore mud volcanoes in Azerbaijan, it is estimated

147 that mean waiting time for weak eruptions of the Chirag mud volcano is 95 years and

148272 years for the average and strong eruptions, respectively (Lerche \& Bagirov 1999).

149 High resolution geophysical imagery is currently being used to monitor hydrocarbon

150 seepage, mud flows and the formation of slope failure scars in order to provide a better

151 understanding of the activity of this mud volcano (Hill et al. 2015; Unterseh \& Contet

152 2015). 


\section{Modelling background}

155

156

157

158

159

160

161

162

163

164

165

166

167

168

169

170

171

172

173

174

175

176

177

178

\section{Analytical and empirical correlations used in this study}

Several analytical and empirical correlations between P-wave velocity and mechanical

properties / in-situ stresses have been developed which allow the latter to be estimated from the former (e.g. Zoback 2007, p. 113-116; Mavko et al. 2009, p. 386-388). The empirical correlations are intended to represent the average behaviour of a wide range of lithologies, and so their usefulness is limited by how sensitive the correlated property is to the differences in lithology encountered in the region of interest as well as to any other variable that has not been accommodated within the fitted equation. Nevertheless, albeit with this caveat, such correlations are being used to develop increasingly sophisticated geomechanical models, particularly when more comprehensive input data, such as pre-stack depth migrated (PSDM) seismic inversion, S-wave velocities and borehole information, is also available to provide additional constraints (e.g. White et al. 2007; Sengupta et al. 2011; Gray et al. 2012).

In this study, we have only a very restricted dataset (primarily P-wave). The unavailability of more comprehensive datasets imposes limits on the extent to which we can validate our model results. However the results can be viewed as representative for the context and methodology can be readily applied and tested for more sophisticated dataset in the Caspian and beyond.

and so our comments in this respect are based on whether or not the model results seem realistic given the geomechanical context of the ACG.

The empirical correlations used to infer physical properties and stress states are listed in Table 1. Gradients of overburden, pore fluid pressure and fracture pressure have been evaluated as the change of magnitude of the given quantity over given change in depth. 
179 Given the limited dataset, elastic rock properties were approximated as isotropic 180 throughout the study. The matrix density $\left(\rho_{\text {matrix }}=2600 \mathrm{~kg} / \mathrm{m}^{3}\right)$ in Table 1, Eq. 3 was 181 approximated assuming that the rock is an aggregate of clay minerals comprising $32.5 \%$ 182 montmorillonite, $43.5 \%$ illite, $17.5 \%$ kaolinite, $6.5 \%$ chlorite, which is applicable for the 183 Northwest SCB at a depth range of 1-2 km (Buryakovsky et al. 1995). Pore fluid density 184 ( $\rho_{\text {fluid }}$ ) was approximated as $1000 \mathrm{~kg} / \mathrm{m}^{3}$ (Tozer \& Borthwick 2010). The horizontal 185 stress formula (Table 1, Eq. 11) makes the commonly used approximation of zero 186 horizontal strain (no lateral expansion) which, together with material isotropy, means 187 that the local horizontal stresses are approximated as the same in all directions.

188 Fracture pressure (Table 1, Eq. 14) represents the pressure in the borehole that is 189 needed to cause fracturing of the formation. Assuming zero tensile strength, fracture 190 pressure is given by the minimum horizontal stress.

191 In an attempt to put bounds on the real variation in horizontal stress, the approach of 192 using stress polygons that was introduced by Zoback et al. (1986) and Moos et al. 193 (1990) has been implemented. Stress polygons show permissible ranges of horizontal 194 stresses at a given depth for given pore fluid pressure for each of the three Andersonian 195 fault regimes (Fig. 4). Upper and lower bounds of maximum and minimum horizontal 196 stresses on the stress polygons are constrained by the following relationships derived 197 from the Coulomb failure criterion assuming that one of the principal stresses is vertical 198 (Zoback 2007):

$$
\begin{array}{ll}
\text { Normal fault } & \frac{\sigma_{v}-P_{p}}{\sigma_{h}-P_{p}} \leq\left[\left(\mu^{2}+1\right)^{1 / 2}+\mu\right]^{2} \\
\text { Strike-slip fault } & \frac{\sigma_{H}-P_{p}}{\sigma_{h}-P_{p}} \leq\left[\left(\mu^{2}+1\right)^{1 / 2}+\mu\right]^{2} \\
\text { Reverse fault } & \frac{\sigma_{H}-P_{p}}{\sigma_{v}-P_{p}} \leq\left[\left(\mu^{2}+1\right)^{1 / 2}+\mu\right]^{2}
\end{array}
$$

199 where $\sigma_{v}$ is the vertical principal stress, $\sigma_{H}$ is the maximum horizontal principal stress, $200 \sigma_{h}$ is the minimum horizontal principal stress, $P_{p}$ is the pore fluid pressure and $\mu$ is the 201 coefficient of friction. The diagonal line $\left(\sigma_{H}=\sigma_{h}\right)$ in the diagram is intersected by vertical 202 and horizontal lines which constrain the stress ranges for the different fault regimes.

203 Stress polygons are always above the diagonal line because $\sigma_{H} \geq \sigma_{h}$. 
204 In regions of excess pore pressure (overpressure) differences between the magnitudes

205 of the principal stresses are small and therefore small stress perturbations can lead to a

206 change from one fault regime to another (Zoback 2007).

\section{$207 \quad$ Feasibility calculations}

208 In order to establish that the equations listed in Table 1 return realistic values of

209 material properties and stresses within a South Caspian Basin context, we have

210 evaluated these properties and stresses on an SCB mud volcano for which a structural

211 model exists in the public domain. This is located within the Kurdashi-Araz-Deniz (KAD)

212 anticlinal structure on the western margin of the SCB at a water depth of 30-770 m. The

213 calculations were performed for depths of $500 \mathrm{~m}$ and $1500 \mathrm{~m}$ below sea floor. These

214 were selected from a seismic section across the mud volcano (Soto et al. 2011) to

215 represent points on the structural crest and flank of the mud volcano respectively (Fig.

$2165)$.

217 Hamilton (1979) established a generalized relationship between acoustic wave

218 velocities and depth in marine sediments. This relationship was used to obtain the P-

219 and S-wave values for the crest and flank locations (Fig. 6).

220 The SCB is characterized by abnormally high formation pressures and consequently

221 there have been several studies that have attempted to characterize shale compaction

222 within the basin. The porosity-depth curve compiled by Bredehoeft et al. (1988) (Fig. 7)

223 was used to obtain porosity values for the calculations.

224 Hence the input parameters for the calculations are as listed in Table 2.

225 Using these input parameters and the equations listed in Table 1, the material

226 properties and stresses listed in Table 3 for the crest and flank of the mud volcano were

227 obtained. These are compared in Table 3 with typical ranges of these values for the

228 material properties of clay minerals and poorly consolidated sandstones and

229 mudstones, and with the stress states previously reported in the South Caspian Basin.

230 Our calculated values are consistent with those reported in the literature, and so we

231 have confidence that the empirical correlations detailed in Table 1 are not significantly

232 affected by local factors specific to the South Caspian Basin. 


\section{2D model}

\section{$234 \quad$ Input parameters and procedure}

235 The mechanical properties and stresses on a 2D vertical section across an ACG mud

236 volcano were modelled by digitizing the P-wave velocities presented on a Full

237 Waveform Inversion (FWI) image published by Selwood et al. (2013). The seismic line

238 was $10 \mathrm{~km}$ long by $5 \mathrm{~km}$ deep, in an unknown orientation across one of the mud

239 volcanoes in the Azeri part of the ACG field.

240 The digitization process involved:

241 1. importing the image into MATLAB®;

242 2. reading Red (R), Green (G) and Blue (B) values and replacing these RGB triplets with 243 a single value per pixel;

2443 . replacing each pixel value with the corresponding velocity obtained from the colour 245 bar key to the image;

246 4. generating the 2D synthetic seismic line and writing it as a SEG-Y file;

247 5. importing the SEG-Y file into PETREL® for calculations and visualisation.

248 The resulting P-wave velocity section is shown in Fig. 8. Values of density, porosity and 249 mechanical properties (elastic properties and strength), together with the magnitudes 250 of the principal stresses, pore fluid and fracture pressures were calculated from the P251 wave velocities using the equations listed in Table 1 within the PETREL® software 252 package and are presented here as sections showing the 2D variation of these values. In 253 addition, a vertical pseudo-well (RM-1) located on the structural crest was incorporated 254 into the 2D model to assess the modelled parameters in 1D along the well trajectory. 255 The calculations were performed for an average water depth of $120 \mathrm{~m}$, which is the 256 average water depth in the Azeri field given by the bathymetry data of Hill et al. (2015).

\section{Results}

258 Since the physical properties were calculated solely from P-wave velocity information, 259 the spatial variation of these properties matches that of the P-wave velocity data (Fig.

260 8). The empirical correlations listed in Table 1 do, however, provide the magnitudes of 261 the material properties and how these magnitudes vary across the mud volcano in the 
262 study area. The variation in elastic properties along the pseudo-well is illustrated in Fig.

263 9. The values of these elastic properties at a depth of $500 \mathrm{~m}$ below sea floor are similar

264 to those obtained at this depth on the structural crest of the KAD mud volcano.

265 Bulk density values were estimated using Quijada \& Stewart's method (Table 1. Eq. 2).

266 Quijada \& Stewart (2007) have suggested that in their equation different values of the

267 constants, $a$ and $m$, are applicable for sands ( $a=224.9$ and $m=0.2847$ ) and for shales

$268(a=516.2$ and $m=0.1896)$. In this study the lithology was assumed to be an aggregate of

269 clay minerals, and hence the coefficients for shales were used. Fig. 10 shows the

270 variation of bulk density across the 2D section and along the pseudo-well. The values of

271 bulk density are consistent with the bulk density values calculated at the corresponding

272 positions on the KAD mud volcano. Within the vicinity of the mud volcano feeder system

273 relatively small bulk densities persist to greater depths, presumably because the

274 lithologies are in a brecciated and/or fluidised state.

275 Theoretical and inferred porosity ( $t$ and , respectively) values were computed along

276 the crestal pseudo-well RM-1 using Table 1, Eqs. 3 and 4 (Fig. 11). The theoretical

277 porosity curve assumes a normal compaction trend. The 'pressure transition zone'

278 defined as the depth interval between when the inferred porosity curve starts to deviate

279 from the theoretical porosity profile and when the rate of decrease of inferred porosity

280 with depth significantly decreases (Swarbrick \& Osborne 1996), lies between 620

281 metres below sea floor (mbsf) and $2600 \mathrm{mbsf}$ at the crestal pseudo-well RM-1.

282 Values of pore fluid pressure and fracture pressure have been calculated along the

283 pseudo-well RM-1 (Fig. 12). Estimated pore fluid pressures over the depth range 2-5 km

284 are about 1.4-1.8 times hydrostatic pressure in agreement with previous estimates of

285 shale pore fluid pressure within the South Caspian Basin (Bredehoeft et al. 1988;

286 Javanshir et al. 2015). On the 2D section relatively small pore fluid pressures are seen to

287 persist to a depth of 620 mbsf in areas close to the mud volcano (Fig. 13), and these

288 perhaps represent areas that have not yet fully recharged following recent eruptions.

289 The friction angle increases with depth but with anomalously small values in the

290 volcano vent area (Fig. 14), perhaps reflecting the relatively unconsolidated state of the

291 sediments in this area. At depths greater than $\sim 2500 \mathrm{~m}$, the friction angle values are in

292 good agreement with the frictional properties given by Byerlee's law (Schön 2011). 


\section{Discussion}

$294 \quad$ Fluid flow

295 The spatial variation of fluid overpressure provides information about the direction of

296 fluid flow near the mud volcano. In Fig. 15 fluid overpressure is plotted as overpressure

297 abnormality factor, which is defined as the ratio of pore fluid pressure to hydrostatic

298 pressure. The study area reveals an abnormality factor of $\sim 1.2$ in the first $620 \mathrm{mbsf}$,

$299 \sim 1.5$ in the depth range of 620-2600 mbsf and $\sim 1.8$ from 2600 up to 5000 mbsf. As well

300 as decreasing upwards, fluid overpressure decreases from the flanks towards the

301 structural crest of the mud volcano, implying that a component of the regional fluid flow

302 is being directed laterally from the flanks to the crest. These observations support the

303 suggestion that the perceived drive for the mud volcanoes in the offshore South Caspian

304 Basin involves lateral as well as upward pressure transfer. They also point to the

305 possibility of using P-wave data, particularly if supported with direct fluid pressure

306 measurements, to assess fluid flow pathways within the stratigraphy.

\section{$307 \quad$ Contemporary stress regime}

308 The orientation of the present day stress field is commonly assessed using earthquake

309 focal mechanism solutions and borehole stress orientation measurements. However, it

310 has also been noted that when $\sigma_{H} \neq \sigma_{h}$ mud volcano calderas have a tendency to be

311 elliptical with the long axis oriented parallel to $\sigma_{h}$ (Bonini 2012). While analysing the

312 bathymetry image from the Azeri side of the ACG field (Hill et al. 2015), we have

313 observed that both mud volcano calderas present in the region of interest are elliptical

314 (Fig. 16a). In each case, the long axis of the caldera is oriented NW-SE, parallel to the

315 orientation of Absheron-Balkhan uplift zone, while the short axis is oriented NE-SW.

316 This implies that $\sigma_{h}$ is oriented NW-SE and $\sigma_{H}$ is oriented NE-SW. This is consistent with

317 focal mechanism studies performed over the basin (Ritz et al. 2006; Jackson et al. 2012),

318 with borehole breakout data in the World Stress Map database (Heidbach et al. 2008),

319 and with the direction of maximum regional compressive stress inferred from the NE-

320 SW directed subduction of the South Caspian basement beneath the Absheron-Balkhan

321 uplift (Fig. 16b). 
322 An analysis using stress polygons provides further constraints on the stress state. These 323 have been calculated at three different depths along the pseudo-well RM-1 using Eqs. 1-

324 3. So that the three stress polygons can be compared on a single plot, following Zoback

325 (2007) the stresses obtained using Eqs. 1-3 have been normalized by the depth at which 326 each was obtained and so are presented as $\mathrm{MPa} / \mathrm{m}$. The input values of vertical stress,

327 pore fluid pressure and coefficient of friction are those at the given depth in the pseudo-

328 well RM-1, while the minimum and maximum horizontal stress values have been

329 obtained by manipulating Eqs. 1 and 3, respectively. The values obtained are listed in

330 Table 4, and the resulting stress polygons are shown in Fig. 17. We find that the stress

331 polygons shrink with increasing depth, as overpressure increases. This finding is

332 consistent with the notion that the principal stresses tend to become closer to the

333 vertical stress in magnitude with increasing depth in overpressured areas, and hence

334 that relatively small changes in the stress field can lead to a shift from one Andersonian

335 fault regime to another (Zoback 2007).

\section{Implications on drillability}

337 Pore fluid pressure and fracture pressure, together with their corresponding depth 338 gradients, are central considerations when establishing safe drilling strategies. Whilst

339 knowledge of the actual magnitudes of these pressures is important for drilling 340 activities, knowledge of their gradients is more practical, as the required drilling mud 341 weight is estimated in pressure gradients. The pore pressure gradient characterizes the 342 minimum (or the lower bound) mud weight and the fracture gradient indicates the 343 maximum (or the upper bound) mud weight (Eaton 1969). Identifying upper and lower 344 bounds on the fracture gradient itself is generally good practice when using estimates of 345 fracture gradient. The lower bound is defined as the fracture closure pressure, which is 346 best measured by a leak-off test, while the upper bound indicates a point at which mud 347 loss from the borehole to induced fractures occurs (Zhang 2011). Estimating these 348 bounds requires knowledge of the magnitudes of the horizontal stresses, the tensile 349 strength, and the thermal stress induced by the difference between the mud and 350 formation temperatures. Since we do not have these parameters, we have used a 351 method by Mathews \& Kelly (1967) (Table 1, Eq. 14) to determine fracture pressure and 352 its gradient. This method provides a value similar to the lower bound on the fracture 353 gradient. Fig. 18 shows the pressures and gradients estimated for the crestal pseudo- 
354 well RM-1. The large fluctuations in the pore fluid pressure gradient at shallow depths

355 (>500 mbsf) are probably artefacts arising from the resolution of the P-wave velocity

356 and how this impacts on the calculated porosity used to estimate pore fluid pressure

357 (Table 1, Eq. 13). However, the changes in the slope of the depth variation of pore fluid

358 and fracture gradient that occurs at 620 and $2600 \mathrm{mbsf}$ correlate with the top and base

359 of pressure transition zone identified in Fig. 11.

360 We have attempted to define the safe drilling window (where drilling window is defined

361 as the difference between the fracture gradient and the pore fluid pressure gradient)

362 using our results (Fig. 19). We observe that above a depth of $\sim 300 \mathrm{mbsf}$, on one flank of

363 the mud volcano the drilling window gradients are as small as $\sim 0.003 \mathrm{MPa} / \mathrm{m}$, whereas

364 on the other flank the gradients are larger (up to $0.012 \mathrm{MPa} / \mathrm{m}$ ). The model identifies

365 some areas with large drilling window gradients that are close to the mud volcano

366 feeder pipe. These may represent zones of fluid recharging and so may be transient

367 features. Fluid venting pipes are known to extend down to around $2 \mathrm{~km}$ beneath the

368 seabed in the ACG (Javanshir et al. 2015), which almost marks the base of pressure

369 transition zone (2600 mbsf) in this study. The areas below the pressure transition zone

370 are characterized by the drilling window gradients of $0.004 \mathrm{MPa} / \mathrm{m}$, which decrease to

$3710.002 \mathrm{MPa} / \mathrm{m}$ with increasing depth. We interpret these values as estimates of the

372 drilling window for deep overpressured sections where well consolidated sediments 373 reside.

\section{$374 \quad$ Limitations of this study}

375 Key sources of data for full geomechanical modelling include seismic and borehole data,

376 while geological and drilling data are used for calibration purposes. Geological and

377 seismic data provide regional scale information for the entire section (overburden,

378 underburden and zone of interest), whereas drilling and borehole data aid in focusing

379 on a zone of interest with greater accuracy and higher resolution.

380 The analysis in this study is built almost entirely on P-wave velocity and therefore is

381 sensitive to how tightly constrained the empirical correlations between P-wave velocity

382 and the various mechanical properties and stresses are. A key limitation imposed by

383 the nature of the data is the lack of opportunity to incorporate mechanical anisotropy.

384 Given that the most significant causes of mechanical anisotropy are (a) oriented 
385 fractures, (b) textural alignment of highly anisotropic minerals, and (c) compositional

386 banding, one can expect that the mechanical properties of a fractured, well-bedded, clay

387 mineral rich sequence will be anisotropic. Hence considerable confidence could be

388 added to the findings presented here if data that allowed mechanical anisotropy to be

389 quantified (e.g., AVO, VSP, multi-, wide-, rich and full-azimuth seismic) were available.

390 Nevertheless, even with the limited data available, the findings are consistent with the

391 geodynamic context of this part of the South Caspian Basin.

\section{Conclusions}

393 A 2D P-wave velocity dataset was used with empirical correlations between P-wave and

394 various mechanical properties to build a geomechanical model of the area around a mud

395 volcano in the South Caspian Basin. The key findings are:

396 - realistic values of elastic and brittle strength properties together with fluid

397 pressures can be obtained using the empirical correlations;

398 - sections showing the spatial variation of pore fluid overpressure around the mud

399 volcanoes calculated from P-wave velocity data have considerable potential for

$400 \quad$ constraining models of fluid flow around these structures;

401 - preliminary estimates based on seismic velocities provide useful reconnaissance

402 indications of regions that are safe to drill, regions that are risky, and regions that

403 should be avoided.

404 Taken together, these findings help to reinforce the observation that a considerable

405 body of geomechanical information can be recovered even from very limited seismic

406 datasets, and that this can be useful both for defining targets for more comprehensive

407 geomechanical studies and for providing guidance on drilling strategies.

\section{Acknowledgements}

409 This work was funded by the Ministry of Education of Republic of Azerbaijan. The

410 authors would like to thank Peter Cook from BP Exploration (Caspian Sea) Limited, for

411 the discussions that helped shape the preliminary concepts of the feasibility study. We

412 gratefully acknowledge the comments of Ravan Gulmammadov on an earlier version of

413 the manuscript and Andrew M.W. Newton for his assistance on extracting and

414 processing the bathymetric map of the study area. We would also like to acknowledge 
415 the use of SeisLab, which is a set of MATLAB codes for reading and writing standard

416 SEG-Y files that has been placed in the public domain by Eike Rietsch. David Iacopini

417 and an anonymous reviewer are thanked for their constructive feedback. We thank

418 Schlumberger for the provision of Petrel.

\section{References}

420 ABRAmS, M.A. \& NARIMANOV, A.A. 1997. Geochemical evaluation of hydrocarbons and their

421 potential sources in the western South Caspian depression, Republic of

422 Azerbaijan. Marine and Petroleum Geology Petroleum Geology, 14, 451-468, doi:

423 10.1016/S0264-8172(97)00011-1.

424 Allen, P.A. \& Allen, J.R. 2013. Basin Analysis: Principles and Application to Petroleum

425 Play Assessment, 3rd ed. Wiley-Blackwell.

426 Avseth, P., MukerJi, T. \& Mavko, G. 2010. Quantitative Seismic Interpretation: Applying

427 Rock Physics to Reduce Interpretation Risk, 1st ed. Cambridge University Press.

428 AzZARo, E., BellanCA, A. \& NerI, R. 1993. Mineralogy and geochemistry of Mesozoic black

429 shales and interbedded carbonates, southeastern Sicily: Evaluation of diagenetic

$430 \quad$ processes. Geological Magazine, 130, 191-202, doi:

$431 \quad 10.1017 /$ S0016756800009857.

432 BonINI, M. 2008. Elliptical mud volcano caldera as stress indicator in an active

433 compressional setting (Nirano, Pede-Apennine margin, northern Italy). Geology,

$434 \quad 36,131-134$, doi: $10.1130 /$ G24158A.1.

435 BoninI, M. 2012. Mud volcanoes: Indicators of stress orientation and tectonic controls.

436 Earth-Science Reviews, 115, 121-152, doi: 10.1016/j.earscirev.2012.09.002.

437 Bonini, M. 2013. Fluid seepage variability across the external Northern Apennines

438 (Italy): Structural controls with seismotectonic and geodynamic implications.

439 Tectonophysics, 590, 151-174, doi: 10.1016/j.tecto.2013.01.020.

440 Bredehoeft, J.D., DJeVAnshiR, R.D. \& Belitz, K.R. 1988. Lateral fluid flow in a compacting

441 sand-shale sequence: South Caspian Basin. AAPG Bulletin, 72, 416-424, doi:

442 10.1306/703C9A1E-1707-11D7-8645000102C1865D. 
443

444

445

446

447

448

449

450

451

452

453

454

455

456

457

458

459

460

461

462

463

464

465

466

467

468

469

470

Bristow, C.R., Gale, I.N., Fellman, E., Cox, B.M., Wilkinson, I.P. \& Riding, J.B. 2000. The lithostratigraphy, biostratigraphy and hydrogeological significance of the mud springs at Templars Firs, Wootton Bassett, Wiltshire. Proceedings of the Geologists' Association, 111, 231-245, doi: 10.1016/S0016-7878(00)80016-4.

Buryakovsky, L. A., Chilingar, G. V. \& Aminzadeh, F. 2001. Petroleum Geology of the South Caspian Basin, 1st ed. Elsevier, doi: 10.1016/B978-088415342-9/50000-X.

Buryakovsky, L.A., DJeVAnshiR, R.D. \& ChilingaR, G. V. 1995. Abnormally-high formation pressures in Azerbaijan \& the South Caspian Basin (as related to smectite ? illite transformations during diagenesis \& catagenesis). Journal of Petroleum Science and Engineering, 13, 203-218, doi: 10.1016/0920-4105(95)00008-6.

BYERLEE, J. 1978. Friction of rocks. Pure and Applied Geophysics, 116, 615-626, doi: 10.1007/BF00876528.

Calvès, G., HuUSE, M., SCHWAB, A. \& ClifT, P. 2008. Three-dimensional seismic analysis of high-amplitude anomalies in the shallow subsurface of the northern Indus Fan: Sedimentary and/or fluid origin. Journal of Geophysical Research, 113, 1-16, doi: 10.1029/2008JB005666.

Carragher, P.D., Ross, A., Roach, E., Trefry, C., Talukder, A. \& Stalvies, C. 2013. Natural seepage systems at Biloxi \& Dauphin domes and Mars mud volcano, north east Mississippi Canyon protraction area, Gulf of Mexico. Offshore Technology Conference, 1-19.

Cartwright, J., Huuse, M. \& Aplin, A. 2007. Seal bypass systems. AAPG Bulletin, 91, 11411166, doi: 10.1306/04090705181.

Castagna, J.P., Batzle, M.L. \& EAstwood, R.L. 1985. Relationships between compressional-wave in elastic silicate rocks and shear-wave velocities. Geophysics, 50, 571-581, doi: 10.1190/1.1441933.

ChAnG, C., ZoBACK, M.D. \& KHAKSAR, A. 2006. Empirical relations between rock strength and physical properties in sedimentary rocks. Journal of Petroleum Science and Engineering, 51, 223-237, doi: 10.1016/j.petrol.2006.01.003. 
471

472

473

474

475

476

477

478

479

480

481

482

483

484

485

486

487

488

489

490

491

492

493

494

495

496

497

Clarke, R.H. \& Cleverly, R.W. 1991. Petroleum seepage and post-accumulation migration. Geological Society of London, Special Publications, 59, 265-271, doi: 10.1144/GSL.SP.1991.059.01.17.

CONTET, J. \& UnTERSEH, S. 2015. Multiscale site investigation of a giant mud-volcano offshore Azerbaijan - Impact on subsea field development. Offshore Technology Conference, OTC-25864, 1-10, doi: 10.4043/25864-MS.

DAVIES, R.J. \& STEWART, S.A. 2005. Emplacement of giant mud volcanoes in the South Caspian Basin: 3D seismic reflection imaging of their root zones. Journal of the Geological Society, 162, 1-4, doi: 10.1144/0016-764904-082.

DeVILLE, E., BATTANI, A., ET AL. 2003. The origin and processes of mud volcanism: New insights from Trinidad. Geological Society of London, Special Publications, 216, 475-490, doi: 10.1144/GSL.SP.2003.216.01.31.

Dimitrov, L.I. 2002. Mud volcanoes - The most important pathway for degassing deeply buried sediments. Earth-Science Reviews, 59, 49-76, doi: 10.1016/S00128252(02)00069-7.

EATON, B. 1969. Fracture gradient prediction and its application in oilfield operations. Journal of Petroleum Technology, 21, 1353-1360, doi: 10.2118/2163-PA.

Evans, R., DAvies, R. \& STEWART, S. 2006. Mud volcano evolution from 3D seismic interpretation and field mapping in Azerbaijan. In: AAPG/GSTT Hedberg Conference: Mobile Shale Basins - Genesis, Evolution \& Hydrocarbon Systems Abstracts.

EVANS, R.J., DAVIES, R.J. \& STEWART, S.A. 2007. Internal structure and eruptive history of a kilometre-scale mud volcano system, South Caspian Sea. Basin Research, 19, 153-163, doi: 10.1111/j.1365-2117.2007.00315.x.

Evans, R.J., StEWART, S.A. \& DAVIES, R.J. 2008. The structure and formation of mud volcano summit calderas. Journal of the Geological Society, 165, 769-780, doi: 10.1144/0016-76492007-118. 
501

502

503

504

505

506

507

508

509

510

511

512

513

514

515

516

517

518

519

520

521

522

523

524

525

526

FESEKER, T., BRown, K.R., ET AL. 2010. Active mud volcanoes on the upper slope of the western Nile Deep-sea fan - First results from the P362/2 cruise of R/V poseidon. Geo-Marine Letters, 30, 169-186, doi: 10.1007/s00367-010-0192-0.

FeyzUllayev, A.A. 2012. Mud volcanoes in the South Caspian Basin: Nature and estimated depth of its products. Natural Science, 04, 445-453, doi: 10.4236/ns.2012.47060.

FEYZULLAYEV, A.A. \& LERCHE, I. 2009. Occurrence and nature of overpressure in the sedimentary section of the South Caspian Basin, Azerbaijan. Energy Exploration \& Exploitation, 27, 345-366.

FeyzULLAyEV, A.A. \& Movsumova, U.A. 2010. The nature of the isotopically heavy carbon of carbon dioxide and bicarbonates in the waters of mud volcanoes in Azerbaijan. Geochemistry International, 48, 517-522, doi: 10.1134/S0016702910050083.

Fjaer, E., Holt, R.M., Horsrud, P., RAAEn, A.M. \& Risnes, R. 2008. Petroleum Related Rock Mechanics, 2nd ed. Elsevier, doi: 10.1016/0148-9062(93)92632-Z.

Foster, D., Fowler, S., McGarrity, J., Riviere, M., Robinson, N., Seaborne, R. \& Watson, P. 2008. Building on BP's large-scale OBC monitoring experience - The Clair and Chirag-Azeri Projects. Society of Exploration Geophysicists, 27, 1632-1637, doi: $10.1190 / 1.3036967$

GARDNER, G.H.F., GARDNER, L.W. \& GREGORY, A.R. 1974. Formation velocity and density The diagnostic basis of stratigraphic traps. Geophysics, 39, 770-780, doi: $10.1190 / 1.1440465$.

Gray, D., ANDERson, P., Logel, J., DelBeCQ, F., Schmidt, D. \& Schmid, R. 2012. Estimation of stress and geomechanical properties using 3D seismic data. First Break, 30, 5968.

Guliyev, I., Aliyeva, E., Huseynov, D., Feyzullayev, A. \& Mamedov, P. 2010. Hydrocarbon potential of ultra deep deposits in the South Caspian Basin (presentation). AAPG European Region Annual Conference, 1-66, doi: http://www.searchanddiscovery.com/documents/2011/10312guliyev/ndx_guli yev.pdf. 
527

528

529

530

531

532

533

534

535

536

537

538

539

540

541

542

543

544

545

546

547

548

549

550

551

552

553

554

555

GuliYEV, I.S., FEIZULAYEV, A.A. \& HuSEYnov, D.A. 2001. Isotope geochemistry of oils from fields and mud volcanoes in the South Caspian Basin, Azerbaijan. Petroleum Geoscience, 7, 201-209, doi: 10.1144/petgeo.7.2.201.

HAMILTON, E.L. 1979. Vp/Vs \& Poisson's ratios in marine sediments and rocks. Acoustical Society of America, 66, 1093-1101, doi: 10.1121/1.383344.

Heidbach, O., Tingay, M., Barth, A., Reinecker, J., Kurfeß, D. \& Müller, B. 2008. The World Stress Map database release 2008 doi:10.1594/GFZ.WSM.Rel2008.

Hill, A.W., Hampson, K.M., Hill, A.J., Golightly, C., Wood, G.A., Sweeney, M. \& Smith, M.M. 2015. ACG field geohazards management: Unwinding the past, securing the future. Offshore Technology Conference, 0TC-25870, 1-22, doi: 10.4043/25870MS.

Hong, W.L., EtioPe, G., YAnG, T.F. \& ChAnG, P.Y. 2013. Methane flux from miniseepage in mud volcanoes of SW Taiwan: Comparison with the data from Italy, Romania and Azerbaijan. Journal of Asian Earth Sciences, 65, 3-12, doi: 10.1016/j.jseaes.2012.02.005.

HoRSRUD, P. 2001. Estimating mechanical properties of shale from empirical correlations. SPE Drilling \& Completion, 16, 68-73, doi: 10.2118/56017-PA.

Hovland, M., HiLl, A. \& STOKES, D. 1997. The structure and geomorphology of the Dashgil mud volcano, Azerbaijan. Geomorphology, 21, 1-15, doi: 10.1016/S0169555X(97)00034-2.

HUBBERT, K.M. \& RUBEY, W.W. 1959. Role of fluid pressure in mechanics of overthrust faulting. Part I. Mechanics of fluid-filled porous solids and its application to overthrust faulting. Geological Society of America Bulletin, 70, 115-166, doi: 10.1130/0016-7606(1959)70[167:ROFPIM]2.0.CO;2.

ISLAM, M.A. \& SKALLE, P. 2013. An experimental investigation of shale mechanical properties through drained and undrained test mechanisms. Rock Mechanics and Rock Engineering, 46, 1391-1413, doi: 10.1007/s00603-013-0377-8.

IVERSON, W.P. 1995. Closure stress calculations in anisotropic formations. Society of Petroleum Engineers, 535-548, doi: 10.2118/29598-MS. 
556

557

558

559

560

561

562

563

564

565

566

567

568

569

570

571

572

573

574

575

576

577

578

579

580

581

582

Jackson, J., Priestley, K., Allen, M. \& Berberian, M. 2002. Active tectonics of the South Caspian Basin. Geophysical Journal International, 148, 214-245, doi: 10.1046/j.1365-246X.2002.01005.x.

JAEGer, J.C., COOK, N.G.W. \& Zimmerman, R.W. 2007. Fundamentals of Rock Mechanics, 4th ed. Blackwell Publishing.

JAVANShiR, R.J., Riley, G.W., DupPEnBecker, S.J. \& AbDullayeV, N. 2015. Validation of lateral fluid flow in an overpressured sand-shale sequence during development of AzeriChirag-Gunashli oil field and Shah Deniz gas field: South Caspian Basin, Azerbaijan. Marine and Petroleum Geology, 59, 593-610, doi: 10.1016/j.marpetgeo.2014.07.019.

Jin, Y., YuAN, J., Hou, B., CHEN, M., LU, Y., LI, S. \& Zou, Z. 2012. Analysis of the vertical borehole stability in anisotropic rock formations. Journal of Petroleum Exploration and Production Technology, 2, 197-207, doi: 10.1007/s13202-0120033-y.

Jones, R.W. \& Simmons, M.D. 1997. A review of the stratigraphy of eastern Paratethys (Oligocene-Holocene), with particular emphasis on the Black Sea. Regional and Petroleum Geology of the Black Sea and Surrounding Region: AAPG Memoir 68, 3952.

JUDD, A. 2005. Gas emissions from mud volcanoes: Significance to global climate change. In: Martinelli, G. \& Panahi, B. (eds) Mud Volcanoes, Geodynamics \& Seismicity. Springer Netherlands, 147-157., doi: 10.1007/1-4020-3204-8_13.

KoHLI, A.H. \& ZовACK, M.D. 2013. Frictional properties of shale reservoir rocks. Journal of Geophysical Research: Solid Earth, 118, 5109-5125, doi: 10.1002/jgrb.50346.

Kopf, A., Stegmann, S., Delisle, G., Panahi, B., Aliyev, C.S. \& Guliyev, I. 2009. In-situ cone penetration tests at the sctive Dashgil mud volcano, Azerbaijan: Evidence for excess fluid pPressure, updoming and possible future violent eruption. Marine and Petroleum Geology, 26, 1716-1723, doi: 10.1016/j.marpetgeo.2008.11.005. 
583

584

585

586

587

588

589

590

591

592

593

594

595

596

597

598

599

600

601

602

603

604

605

606

607

608

609

610

LAL, M. 1999. Shale stability: Drilling fluid interaction and shale strength. SPE Latin America and Caribbean Petroleum Engineering Conference, 1-10, doi: 10.2118/54356-MS.

LE PICHON, X., FouCHER, J.-P., ET AL. 1990. Mud volcano field seaward of the Barbados accretionary complex: A deep-towed side scan survey. Journal of Geophysical Research, 95, 8917-8929, doi: 10.1029/JB095iB06p08931.

LERCHE, I. \& BAGIROV, E. 1999. Impact of Natural Hazards on Oil and Gas Extraction - The South Caspian Basin, 1st ed. Springer US.

MagarA, K. 1978. Compaction and Fluid Migration: Practical Petroleum Geology, 1st ed. Elsevier.

MATHEWS, W.R. \& KELLY, J. 1967. How to predict formation pressure and fracture gradient. Oil \& Gas Journal, 7.

Mavko, G., MukerJI, T. \& Dvorkin, J. 2009. The Rock Physics Handbook - Tools for Seismic Analysis of Porous Media, 2nd ed. Cambridge University Press.

Mazzini, A., Svensen, H., Planke, S., Guliyev, I., Akhmanov, G.G., Fallik, T. \& Banks, D. 2009. When mud volcanoes sleep: Insight from seep geochemistry at the Dashgil mud volcano, Azerbaijan. Marine and Petroleum Geology, 26, 1704-1715, doi: 10.1016/j.marpetgeo.2008.11.003.

MiLKov, A. V. 2000. Worldwide distribution of submarine mud volcanoes and associated gas hydrates. Marine Geology, 167, 29-42, doi: 10.1016/S0025-3227(00)000220 .

Moos, D. \& ZовACK, M.D. 1990. Utilization of observations of well bore failure to constrain the orientation and magnitude of crustal stresses: Application to continental, deep sea drilling project and ocean drilling program boreholes. Journal of Geophysical Research, 95, 9305-9325, doi: 10.1029/JB095iB06p09305.

Morton, A., Allen, M., ET AL. 2003. Provenance patterns in a neotectonic basin: Pliocene and Quaternary sediment supply to the South Caspian. Basin Research, 15, 321337, doi: 10.1046/j.1365-2117.2003.00208.x. 
611 Oppo, D., CapozZI, R., Nigarov, A. \& Esenov, P. 2014. Mud volcanism and fluid

612 geochemistry in the Cheleken peninsula, western Turkmenistan. Marine and

613 Petroleum Geology, 57, 122-134, doi: 10.1016/j.marpetgeo.2014.05.009.

614 Pape, T., Feseker, T., Kasten, S., Fischer, D. \& Bohrmann, G. 2011. Distribution and

615 abundance of gas hydrates in near-surface deposits of the Håkon Mosby mud

616 volcano, SW Barents Sea. Geochemistry, Geophysics, Geosystems, 12, 1-22, doi:

$617 \quad 10.1029 / 2011 \mathrm{GC} 003575$.

618 Planke, S., Svensen, H., Hovland, M., Banks, D. A. \& Jamtveit, B. 2003. Mud and fluid

619 migration in active mud volcanoes in Azerbaijan. Geo-Marine Letters, 23, 258-

620 267, doi: 10.1007/s00367-003-0152-z.

621 Plumb, R., EdWards, S., Pidcock, G., LeE, D. \& StAcey, B. 2000. The mechanical earth model 622 concept and its application to high-risk well construction projects. IADC/SPE

623 Drilling Conference, 1-13, doi: 10.2118/59128-MS.

624 PRASAD, M. 2002. Measurement of Young's modulus of clay minerals using atomic force

625 acoustic microscopy. Geophysical Research Letters, 29, 2-5, doi:

$626 \quad 10.1029 / 2001 G L 014054$.

627 QUIJADA, M.F. \& STEWART, R.R. 2007. Density estimation using density-velocity relations

628 and seismic inversion. CREWES Research Report, 19, 1-20.

629 Ritz, J.F., Nazari, H., Ghassemi, A., Salamati, R., Shafei, A., Solaymani, S. \& Vernant, P.

630 2006. Active transtension inside central Alborz: A new insight into northern

631 Iran-southern Caspian geodynamics. Geology, 34, 477-480, doi:

$632 \quad 10.1130 / G 22319.1$.

633 Roberts, K.S., Davies, R.J., Stewart, S. A. \& Tingay, M. 2011. Structural controls on mud 634 volcano vent distributions: examples from Azerbaijan and Lusi, east Java. Journal 635 of the Geological Society, 168, 1013-1030, doi: 10.1144/0016-76492010-158.

636 RubeY, W.W. \& HubBERT, K.M. 1959. Role of fluid pressure in mechanics of overthrust 637 faulting. Part II. Overthrust belt in geosynclinal area of western Wyoming in light 638 of fluid-pressure hypothesis. Geological Society of America Bulletin, 70, 167-206, 639 doi: 10.1130/0016-7606(1959)70[167:ROFPIM]2.0.CO;2. 
640 Santos Betancor, I. \& Soto, J.I. 2015. 3D geometry of a shale-cored anticline in the

641 western South Caspian Basin (offshore Azerbaijan). Marine and Petroleum

642 Geology Petroleum Geology, 67, 829-851, doi: 10.1016/j.marpetgeo.2015.06.012.

643 SснӧN, J. 2011. Physical Properties of Rocks: A Workbook. Elsevier.

644 SElWoOd, C.S., SHAH, H.M. \& BAPTISTE, D. 2013. The evolution of imaging over Azeri, from

645 TTI tomography to anisotropic FWI. 75th EAGE Conference \& Exhibition

646 incorporating SPE EUROPEC 2013, Extended abstract, 1-5.

647 Sengupta, M., Dai, J., Volterrani, S., Dutta, N., RaO, N.S., Al-QAdeeri, B. \& Kidambi, V.K.

648 2011. Building a seismic-driven 3D geomechanical model in a deep carbonate

649 reservoir. SEG Technical Program Expanded Abstracts 2011, 2069-2073, doi:

$650 \quad 10.1190 / 1.3627616$.

651 Smith-Rouch, L.S. 2006. Oligocene-Miocene Maykop/Diatom total petroleum system of

652 the South Caspian Basin province, Azerbaijan, Iran and Turkmenistan. U.S.

653 Geological Survey Bulletin, 2201-I, 1-27.

654 Soto, J.I., SAntos-Betancor, I., SAnchez Borrego, I. \& Macellari, C.E. 2011. Shale diapirism

655 and associated folding history in the South Caspian Basin (Offshore Azerbaijan).

656 AAPG Annual Convention and Exhibition, 30162.

657 STEWART, S.A. \& DAVIES, R.J. 2006. Structure and emplacement of mud volcano systems in 658 the South Caspian Basin. AAPG Bulletin, 90, 771-786, doi:

$659 \quad 10.1306 / 11220505045$.

660 SWARBRICK, R.E. \& OsBoRne, M.J. 1996. The nature and diversity of pressure transition 661 zones. Petroleum Geoscience, 2, 111-116, doi: 10.1144/petgeo.2.2.111.

662 Tozer, R.S.J. \& BorTHWicK, A. M. 2010. Variation in fluid contacts in the Azeri field, 663 Azerbaijan: sealing faults or hydrodynamic aquifer? Geological Society, London, $664 \quad$ Special Publications, 347, 103-112, doi: 10.1144/SP347.8.

665 UNTERSEH, S. \& CONTET, J. 2015. Integrated geohazards assessments offshore Azerbaijan, 666 Caspian Sea. Offshore Technology Conference, OTC-25911, 1-8, doi: $667 \quad 10.4043 / 25911-M S$. 
668 VAnORIO, T., PRASAD, M. \& NUR, A. 2003. Elastic properties of dry clay mineral aggregates, 669 suspensions and sandstones. Geophysical Journal International, 155, 319-326, 670 doi: $10.1046 /$ j.1365-246X.2003.02046.x.

671 White, A., Ward, C., Castillo, D., Magee, M., Trotta, J., McIntyre, B. \& O’Shea, P. 2007.

$672 \quad$ Updating the geomechanical model and calibrating pore pressure from 3D

673 seismic using data from the Gnu-1 Well, Dampier sub-Basin, Australia.

$674 \quad$ Proceedings of Asia Pacific Oil and Gas Conference and Exhibition, 16, doi:

675 10.2118/110926-MS.

676 YuSifov, M. \& RABINOWITZ, P.D. 2004. Classification of mud volcanoes in the South 677 Caspian Basin, offshore Azerbaijan. Marine and Petroleum Geology, 21, 965-975, 678 doi: 10.1016/j.marpetgeo.2004.06.002.

679 Zang, A., Stephansson, O., Heidbach, O. \& Janouschiowetz, S. 2012. World Stress Map 680 database as a resource for rock mechanics and rock engineering. Geotechnical 681 and Geological Engineering, 30, 625-646, doi: 10.1007/s10706-012-9505-6.

682 ZHANG, J. 2011. Pore pressure prediction from well logs: Methods, modifications and 683 new approaches. Earth-Science Reviews, 108, 50-63, doi:

$684 \quad$ 10.1016/j.earscirev.2011.06.001.

685 ZoвасK, M.D. 2007. Reservoir Geomechanics, 1st ed. Cambridge University Press.

686 


\section{Figure captions}

688 Fig. 1. (a) Bathymety of the Caspian Sea and topography of the surrounding countries, 689 showing the location of the offshore South Caspian Basin and the Azeri-Chirag-Guneshly 690 (ACG) structure (map extracted using GEBCO_2014 Grid - a global 30 arc-second interval

691 grid - and processed in ArcMap); (b) Simplified tectonic framework for the offshore South 692 Caspian Basin (modified from Stewart \& Davies 2006)

693 Fig. 2. Simplified stratigraphic column of the South Caspian Basin. Nomenclature: S -

694 source rock, $R$ - reservoir, $C$ - cap rock (modified from Yusifov \& Rabinowitz 2004; Smith-

695 Rouch 2006; Javanshir et al. 2015)

696 Fig. 3. Schematic diagram showing the geometry and key geomechanical properties of the

697 Chirag mud volcano. SSTD - sediment-source top depth, GG - geothermal gradient, PPG -

698 pore-pressure gradient, TH - thickness, Por - porosity, Per - permeability, MCV - mud cone

699 volume, MCT - mud cone thickness, HPE - highest point elevation, SD - surface diameter, WD

700 - water depth, EV - eruption volume, IOD - illitization onset depth, IT - illitization

701 temperature. Superscripts in brackets refer to the references: (1)Evans et al. 2006;

702 (2)Buryakovsky et al. 2001; (3)Stewart \& Davies 2006; (4)Evans et al. 2006; (5)Davies et al.

703 2005; (6)Feyzullayev \& Lerche 2009

704 Fig. 4. Stress polygons defining the upper and lower bounds of the principal horizontal

705 stresses in different fault regimes (modified from Zoback, 2007)

706 Fig. 5. Vertical seismic section of a mud volcano from Kurdashi-Araz-Deniz (KAD) structure

707 in the offshore western SCB (modified from Soto et al. 2011)

708 Fig. 6. Generic $P$ - and $S$-wave velocities vs. depth curves in marine sediments (modified from

709 Hamilton 1979)

710 Fig. 7. Shale compaction curve in northwest SCB (modified from Bredehoeft et al. 1988)

711 Fig. 8: P-wave velocity data generated from the Full Waveform Inversion image published

712 by Selwood et al. (2013). Highlighted is the feeder pipe of the investigated mud volcano

713 Fig. 9. (a) Profiles of elastic rock properties and (b) acoustic wave velocities along the RM-1

714 pseudo-well. Markers indicate the magnitudes of these properties obtained on the structural

715 crest of the KAD mud volcano that was analysed in the feasibility modelling

716 Fig. 10. (a) Vertical cross-section across the ACG showing the variation in bulk density as

717 obtained using Quijada \& Stewart's method with their parameters for shales. (b) The depth

718 variation of bulk density along the pseudo-well RM-1, with the depth variation using

719 Quijada \& Stewart's parameters for sands are also shown for comparison 
720 Fig. 11: Variation in inferred porosity and theoretical porosity along pseudo-well RM-1

721 showing the onset of overpressuring at $620 \mathrm{mbsf}$ and the top of 'hard overpressure' at 2600

$722 \quad m b s f$

723 Fig. 12. Variation in overburden stress and pressures along pseudo-well RM-1

724 Fig. 13: Vertical cross-section across the ACG showing the variation in pore fluid pressure.

725 This highlights the relatively small pore fluid pressures in the shallow unconsolidated

726 sediments and in the vicinity of the mud volcano

727 Fig. 14: (a) Vertical cross-section across the ACG showing the variation of friction angle

728 and (b) the depth variation of friction angle along the pseudo-well RM-1. The marker on the

729 pseudo-well curve indicates the friction angle obtained on the structural crest of the KAD

730 mud volcano that was analysed in the feasibility modelling

731 Fig. 15: (a) Vertical cross-section across the ACG and (b) along the pseudo-well RM-1

732 showing the overpressure abnormality factor. Arrows indicate the inferred direction of fluid

733 flow

734 Fig. 16: Regional horizontal stress states in the ACG field. (a) Elliptical mud volcano (MV)

735 calderas drawn on the ACG bathymetry image of Hill et al. (2015). The inset figure is a

736 conceptual diagram of stress states around a mud volcano located in the structural crest of

737 a larger scale antiform (modified from Bonini 2012). On the structural crest, outer arc

738 extension means that the vertical stress is locally probably the greatest principal stress. (b)

739 World Stress Map displaying borehole breakouts from the ACG overlain by a rose diagram of

740 borehole breakout directions; the data are coloured according to confidence in their quality

741 (with A being the highest quality)

742 Fig. 17. Stress polygons at three depths in pseudo-well RM-1, showing the decreasing

743 permissible ranges of horizontal stresses with increasing depth

744 Fig. 18: Variation of pressure gradients along pseudo-well RM-1

745 Fig. 19. Vertical cross-section across the ACG showing the width of the drilling window. The

746 safest areas to drill are those with the widest drilling window 


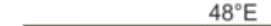

$52^{\circ} \mathrm{E}$

$54^{\circ} \mathrm{E}$

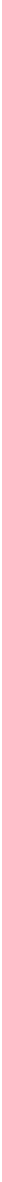




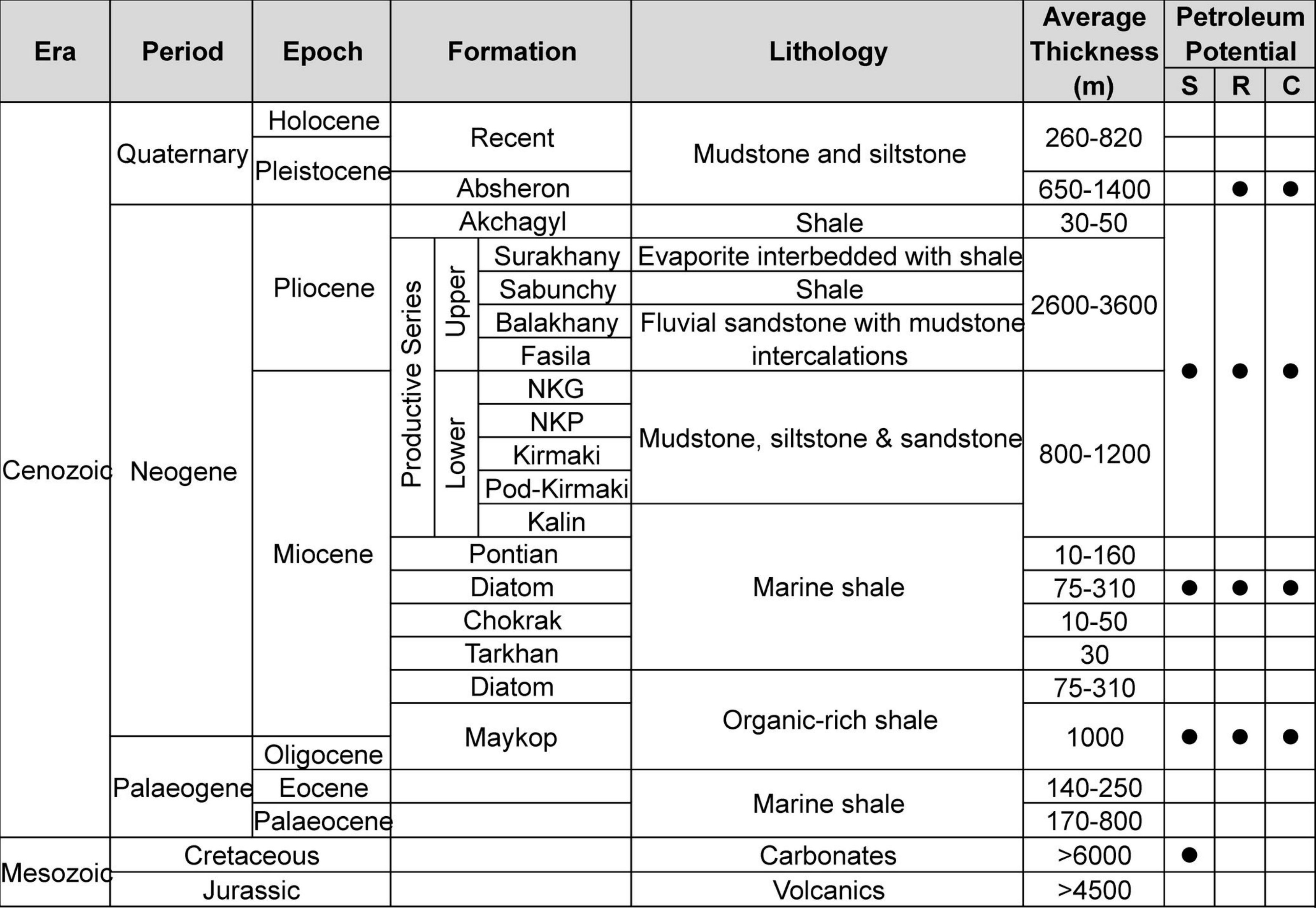




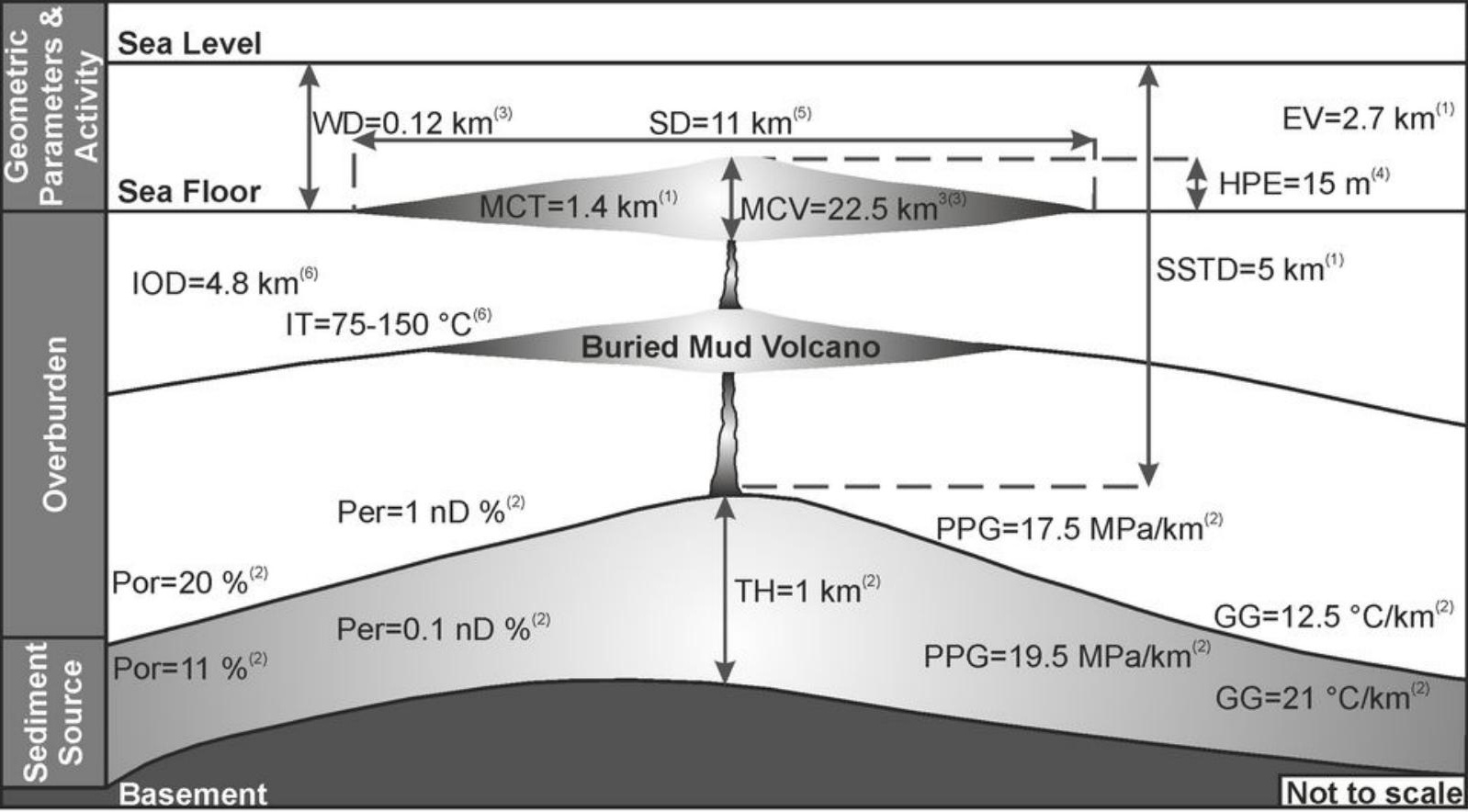




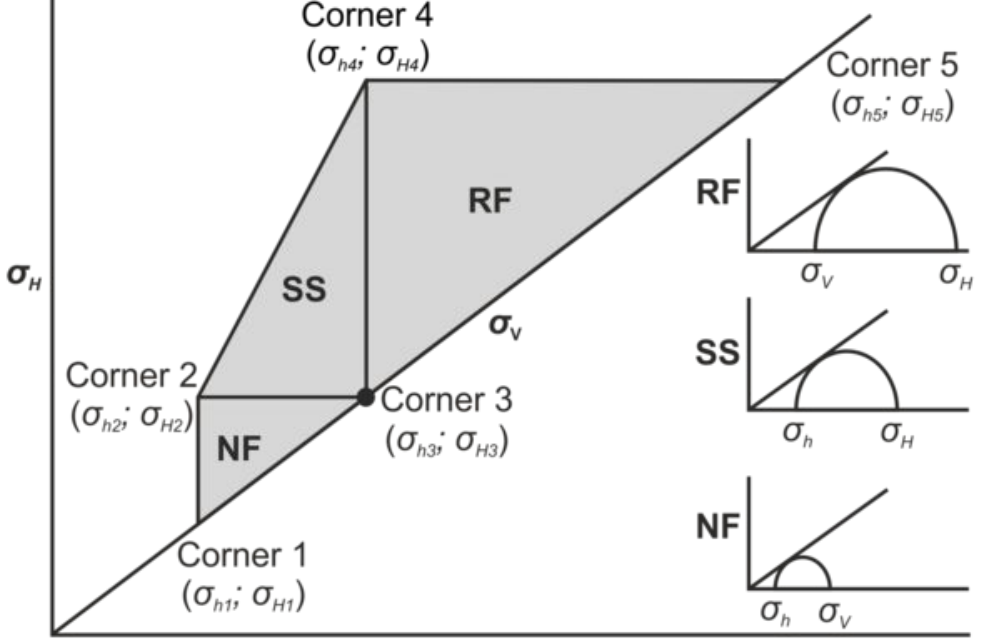

\section{$\sigma_{h}$}

NF - Normal Fault; SS - Strike-slip Fault; RF - Reverse Fault 


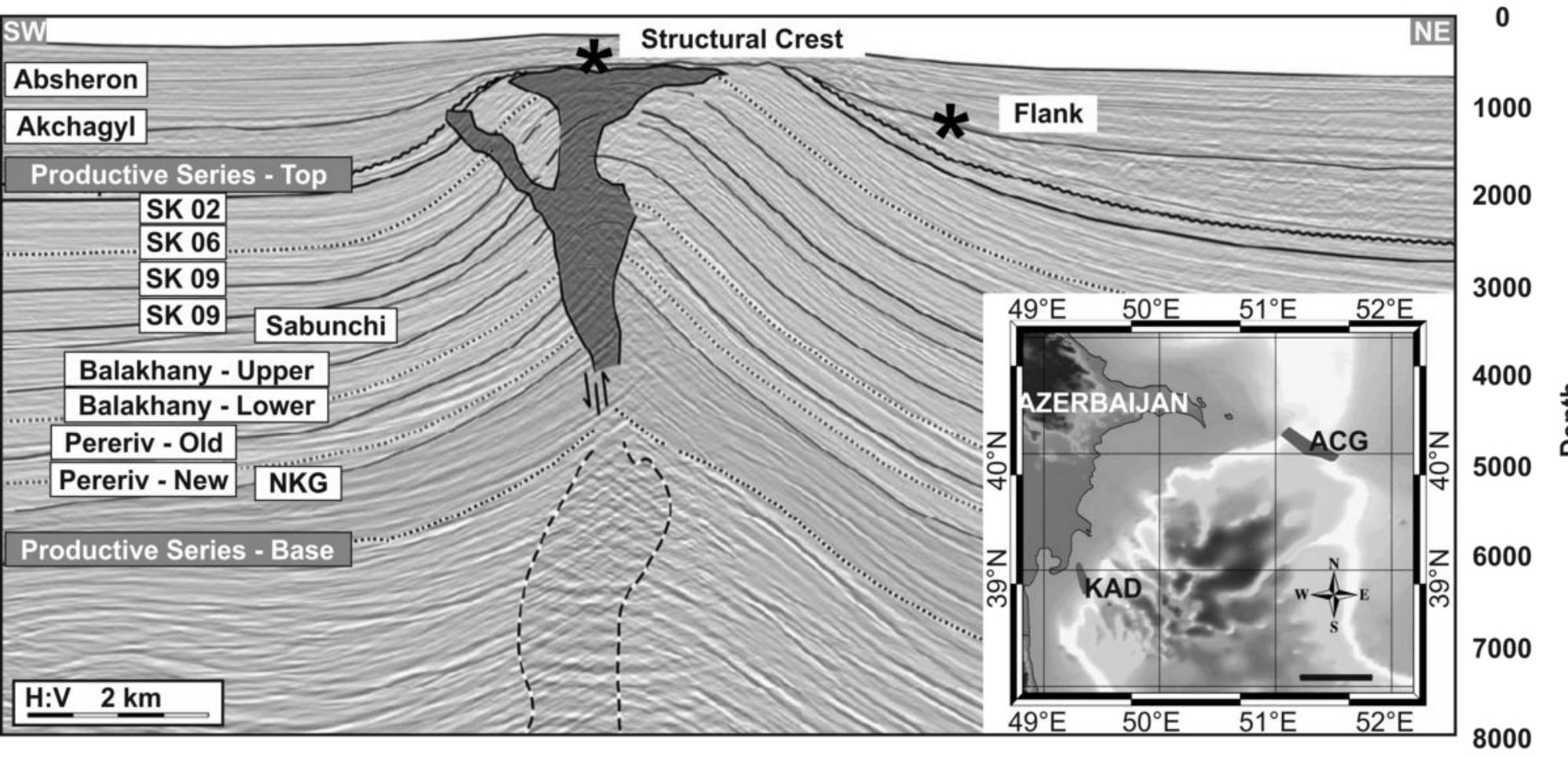


Velocity, km/s

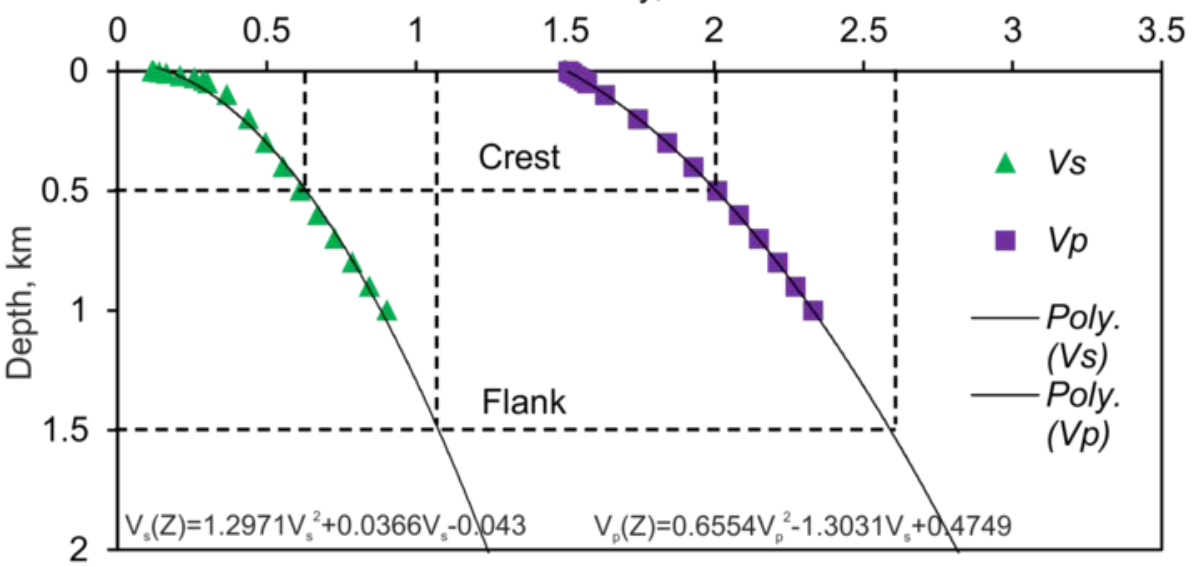


Porosity, \%

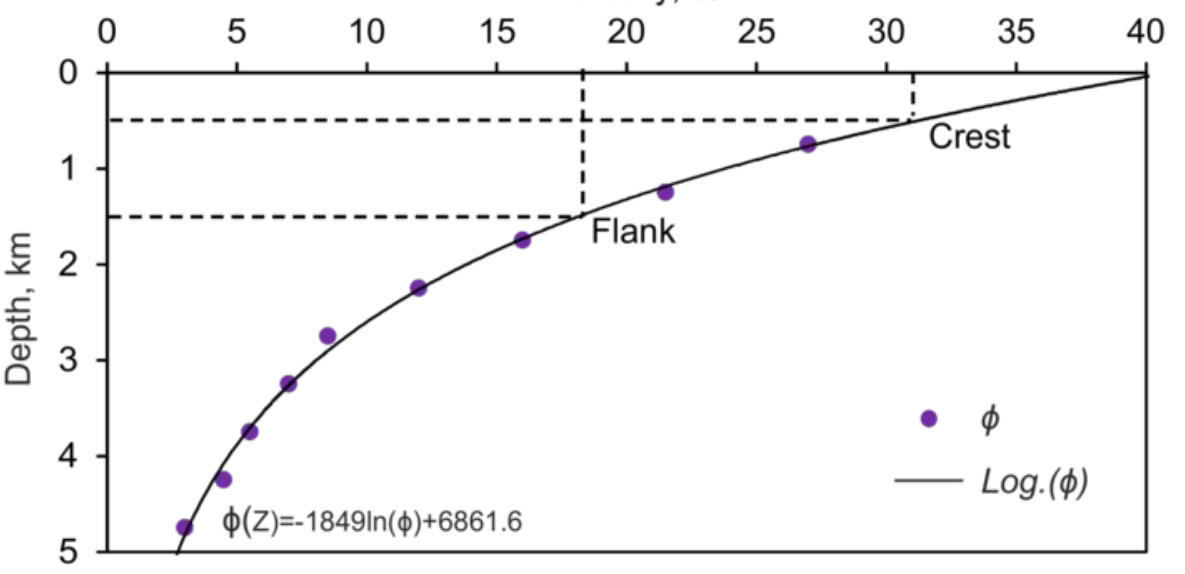




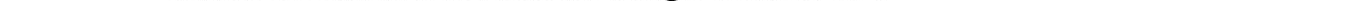




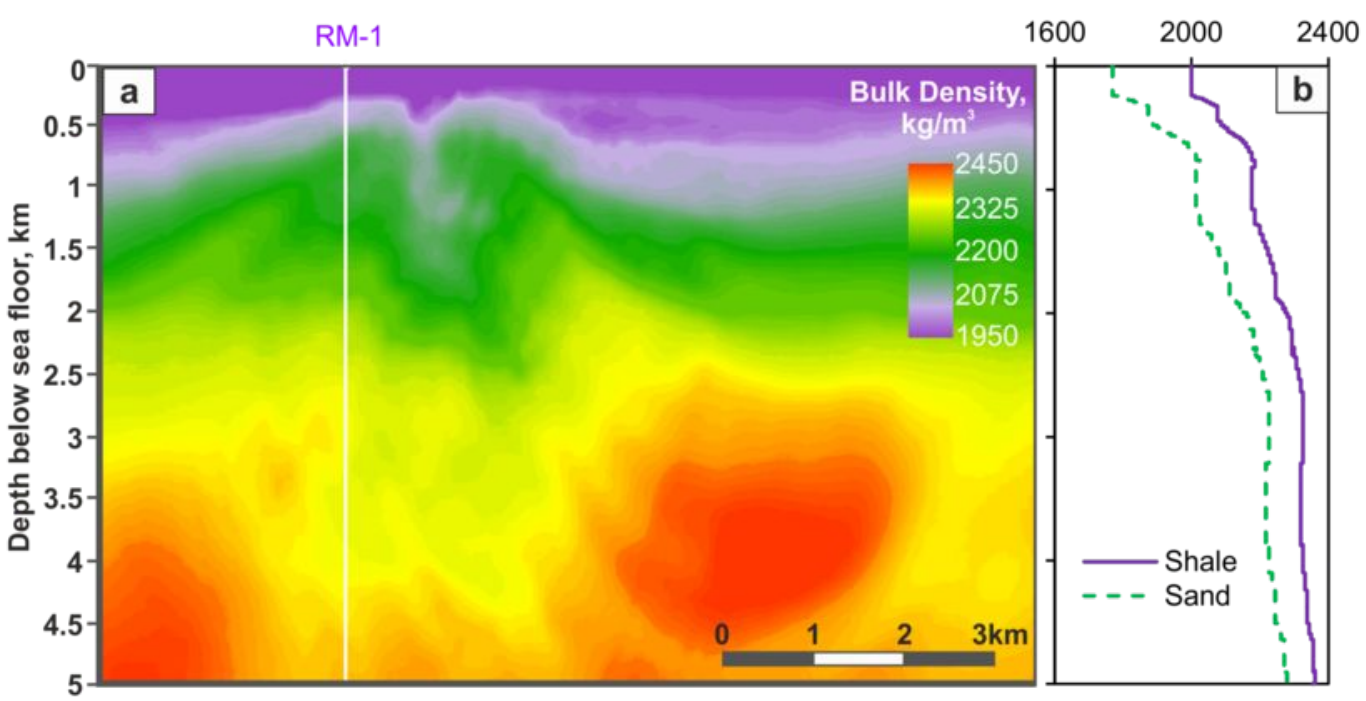


Pressure, MPa

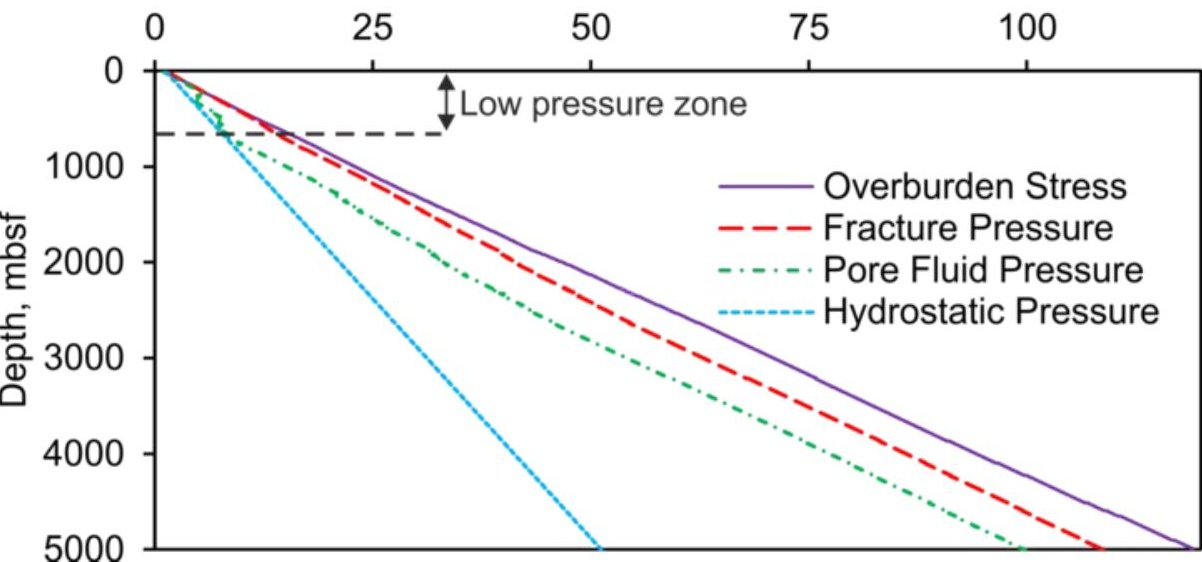




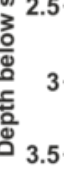

Pore fluid pressure, MPa

뇨 88 

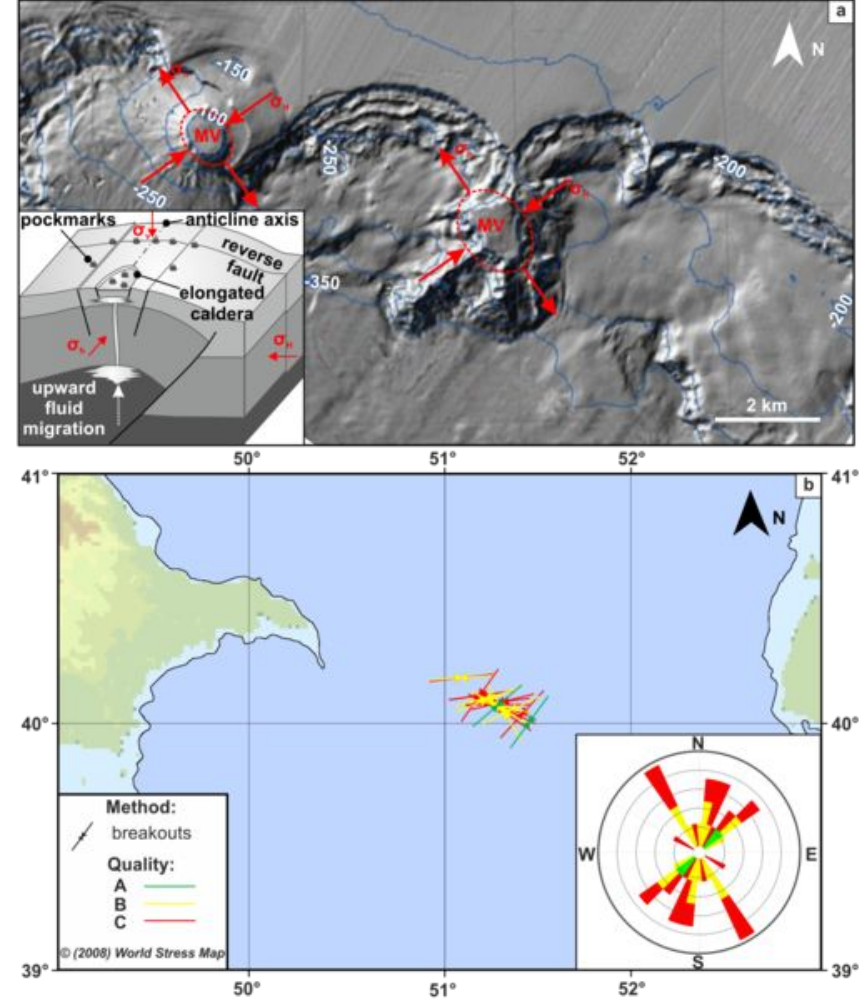


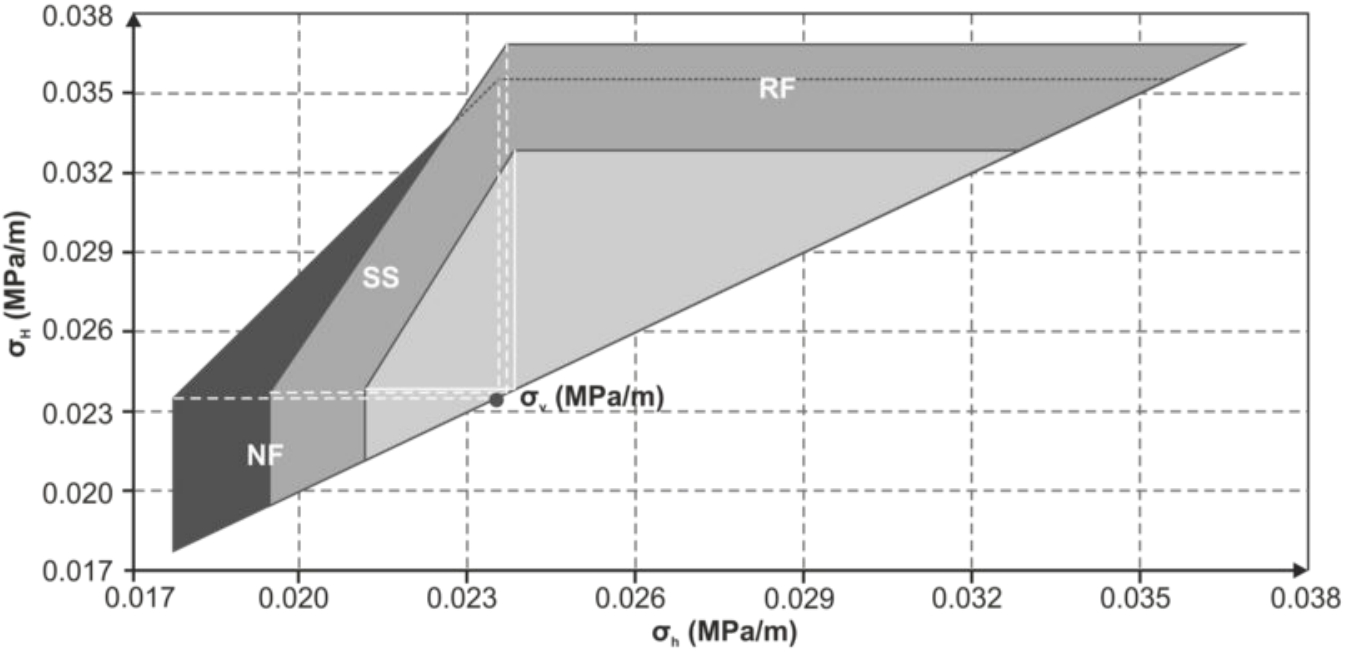

NF - Normal Fault; SS - Strike-slip Fault; RF - Reverse Fault 
Gradient, MPa/m

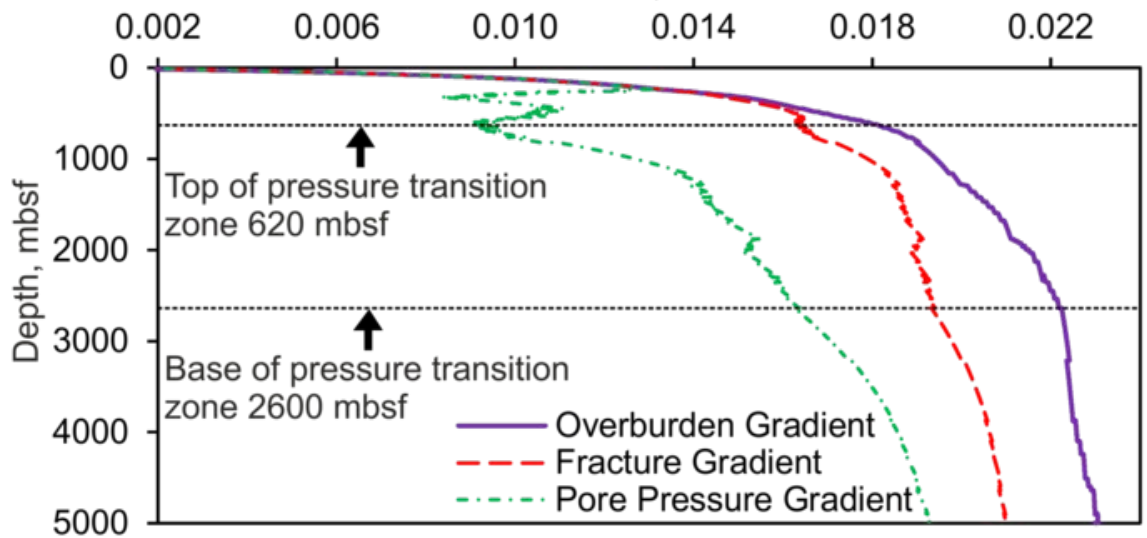




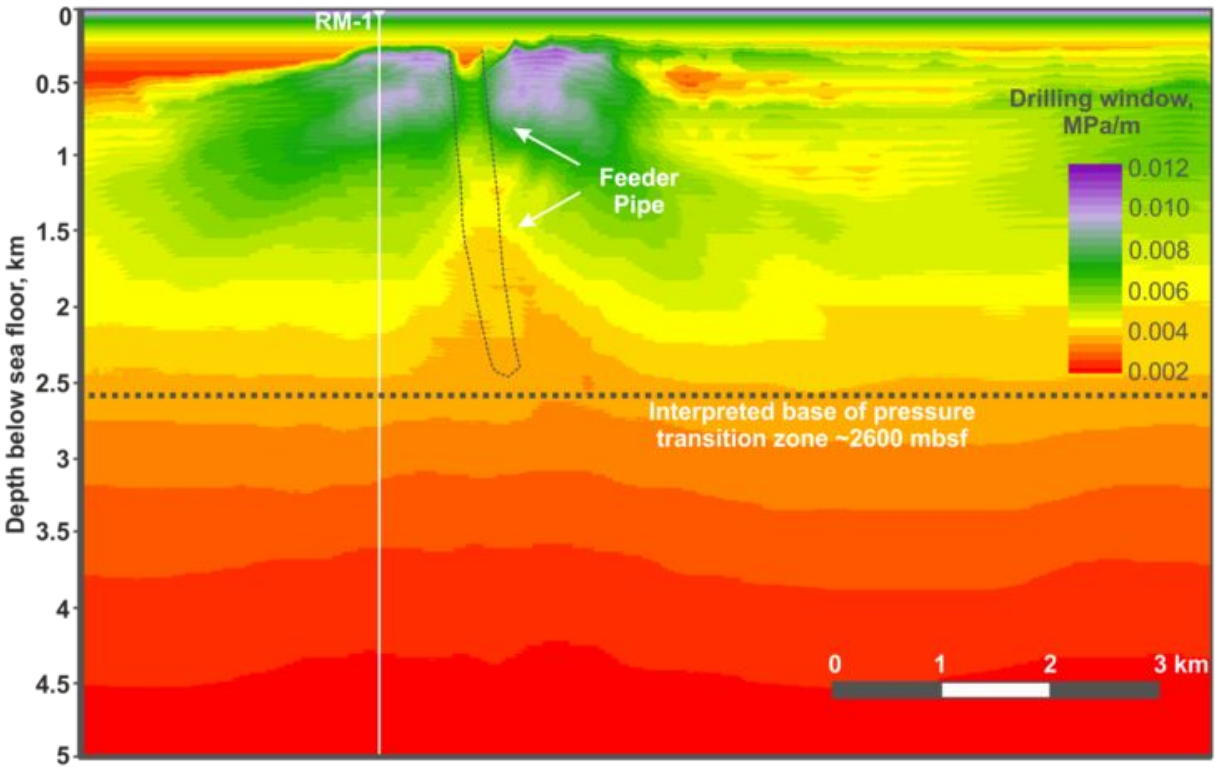


Table 1. Analytical and empirical correlations employed in the study. $V_{p}$ is $\mathrm{km} / \mathrm{s}$. Asterisks in the second column indicate that the relationship is analytical

\begin{tabular}{|c|c|c|c|c|c|c|c|}
\hline Type & $\#$ & PROPERTY & & UNIT & EQUATION & NOTE & REFERENCE \\
\hline \multirow{9}{*}{ 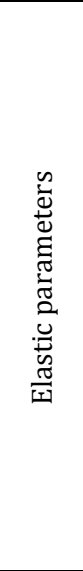 } & 1 & Shear wave velocity & $V_{s}$ & $\mathrm{~km} / \mathrm{s}$ & $0.8621 V_{p}-1.1724$ & Mudrock line for clastics & Castagna et al. 1985, Eq. 1 \\
\hline & 2 & Bulk density & $\rho_{b}$ & $\mathrm{~kg} / \mathrm{m}^{3}$ & $a V_{p}^{m}$ & $\begin{array}{c}\text { Amended Gardner's equation for shales, } \\
\text { where } a=516.2 \text { and } m=0.1869\end{array}$ & Quijada \& Stewart 2007, Table 2 \\
\hline & $3^{*}$ & Porosity & $\phi$ & - & $\left(\rho_{\text {matrix }}-\rho_{b}\right) /\left(\rho_{\text {matrix }}-\rho_{\text {fluid }}\right)$ & $\begin{aligned} \rho_{\text {matrix }}= & 2600 \mathrm{~kg} / \mathrm{m}^{3} \text { and } \rho_{\text {fluid }}=1000 \mathrm{~kg} / \mathrm{m}^{3} . \\
& \text { Explanation follows Table } 1\end{aligned}$ & Avseth et al. 2010, p. 57, Eq. 2.10 \\
\hline & 4 & Theoretical porosity & $\phi_{t}$ & - & $\phi_{0} e^{-\beta \sigma_{v}}$ & $\begin{array}{l}0 \text { is the pre-compaction porosity. } \beta=0.0421 \\
\text { and } 0=0.4\end{array}$ & $\begin{array}{c}\text { Rubey \& Hubbert 1959, Eq. } 16 \\
\text { Buryakovsky et al. 2001, p. } 353,374\end{array}$ \\
\hline & $5^{*}$ & Shear modulus & G & GPa & $\rho_{b} V_{s}^{2}$ & & Mavko et al. 2009, p. 81 \\
\hline & $6^{*}$ & Lamé's constant & $\lambda$ & GPa & $\rho_{b} V_{p}^{2}-2 G$ & & Mavko et al. 2009, p. 81 \\
\hline & $7^{*}$ & Poisson's ratio & $v$ & - & $\left(V_{p}^{2}-2 V_{s}^{2}\right) /\left[2\left(V_{p}^{2}-V_{s}^{2}\right)\right]$ & & Mavko et al. 2009, p. 81 \\
\hline & $8^{*}$ & Young's modulus & E & $\mathrm{GPa}$ & $G\left(3 V_{p}^{2}-4 V_{s}^{2}\right) /\left(V_{p}^{2}-V_{s}^{2}\right)$ & & Mavko et al. 2009, p. 82 \\
\hline & $9^{*}$ & Bulk modulus & K & $\mathrm{GPa}$ & $\rho_{b}\left(3 V_{p}^{2}-4 V_{s}^{2}\right) / 3$ & & Mavko et al. 2009, p. 82 \\
\hline \multirow{5}{*}{ 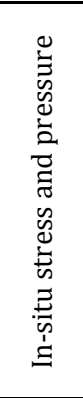 } & $10^{*}$ & Overburden stress & $\sigma_{v}$ & $\mathrm{MPa}$ & $\rho_{w} g z_{w}+\rho_{b} g\left(z-z_{w}\right)$ & $\rho_{w}$ and $z_{w}$ are the density and depth of the & Zoback 2007, p. 8, Eq. 1.6 \\
\hline & 11 & Horizontal stress & $\sigma_{h}$ & $\mathrm{MPa}$ & $\sigma_{v} v /(1-v)$ & $\begin{array}{l}\text { water, respectively } \\
\text { In the calculations we approximate } \sigma_{H} \sim \sigma_{h} \text {, } \\
\text { where } \sigma_{H} \text { and } \sigma_{h} \text { are max. and min. horizontal } \\
\text { stresses, respectively. Explanation of their } \\
\text { permissible magnitudes follows Table } 1\end{array}$ & Iverson 1995, Eq. 4 \\
\hline & $12^{*}$ & Hydrostatic pressure & $P_{h}$ & $\mathrm{MPa}$ & $\rho_{w} g z$ & & Zoback 2007, p. 28, Eq. 2.1 \\
\hline & 13 & Pore Fluid pressure & $P_{p}$ & $\mathrm{MPa}$ & $\sigma_{v}-(1 / \beta) \ln \left(\phi_{0} / \phi\right)$ & $\begin{array}{l}\text { Pressure existing in the pores of the } \\
\text { formation. Derived from Eq. } 4\end{array}$ & Rubey \& Hubbert 1959, Eq. 16 \\
\hline & 14 & Fracture pressure & $P_{f}$ & $\mathrm{MPa}$ & $P_{p}+\left(\sigma_{v}-P_{p}\right)\left(\sigma_{h} / \sigma_{v}\right)$ & Explanation follows Table 1 & Mathews \& Kelly 1967, p. 7 \\
\hline \multirow{3}{*}{ 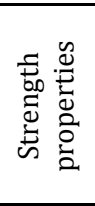 } & 15 & Friction angle & $\varphi$ & $\circ$ & $\sin ^{-1}\left(\left(V_{p}-1\right) /\left(V_{p}+1\right)\right)$ & For shales & Lal 1999, Eq. 17 \\
\hline & 16 & Cohesive strength & $\tau_{0}$ & $\mathrm{MPa}$ & $5\left(V_{p}-1\right) / \sqrt{V_{p}}$ & For shales & Lal 1999, Eq. 17 \\
\hline & 17 & $\begin{array}{l}\text { Uniaxial Compressive } \\
\text { Strength }\end{array}$ & $C$ & $\mathrm{MPa}$ & $1.35 V_{p}^{2.6}$ & For shales, worldwide & Chang et al. 2006, Eq. 14 \\
\hline
\end{tabular}


Table 2. Feasibility model input parameters

\begin{tabular}{lllll}
\hline $\begin{array}{l}\text { Structural } \\
\text { position }\end{array}$ & $\begin{array}{l}\text { Depth, } \\
\mathbf{m}\end{array}$ & $\begin{array}{l}\text { P-wave } \\
\text { velocity, } \mathbf{k m} / \mathbf{s}\end{array}$ & $\begin{array}{l}\text { S-wave } \\
\text { velocity, } \mathbf{k m} / \mathbf{s}\end{array}$ & $\begin{array}{l}\text { Porosity, } \\
\mathbf{\%}\end{array}$ \\
\hline Crest & 500 & 2.015 & 0.638 & 30 \\
Flank & 1500 & 2.591 & 1.076 & 17 \\
\hline
\end{tabular}


Table 3. Modelled values of elastic properties, state of stress and rock strength on the crest and flank of a mud volcano from the KAD structure

\begin{tabular}{|c|c|c|c|c|c|c|}
\hline \multicolumn{3}{|c|}{ Estimated parameters } & \multicolumn{2}{|c|}{ Structural position } & \multicolumn{2}{|c|}{ Values from the literature } \\
\hline Type & Name & Unit & Crest & Flank & Range & Reference \\
\hline \multirow{6}{*}{ 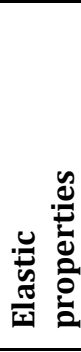 } & Bulk density & $\mathrm{kg} / \mathrm{m}^{3}$ & 2140 & 2243 & $1580-2600$ & $\begin{array}{l}\text { Mavko et al. 2009, p. } \\
458,459\end{array}$ \\
\hline & Shear modulus & $\mathrm{GPa}$ & 0.87 & 2.60 & $0.2-5.5$ & Horsrud 2001, p. 71 \\
\hline & Lamé's constant & GPa & 8.69 & 15.06 & $0.07-13.26$ & $\begin{array}{l}\text { Islam \& Skalle 2013, p. } \\
1400\end{array}$ \\
\hline & Poisson's ratio & - & 0.44 & 0.40 & $0.35-0.50$ & Schön 2011, p 162 \\
\hline & Young's modulus & $\mathrm{GPa}$ & 2.52 & 7.25 & $3.2-9.5$ & Prasad et al. 2012, p. 3 \\
\hline & Bulk modulus & $\mathrm{GPa}$ & 7.53 & 11.59 & $6-12$ & $\begin{array}{l}\text { Vanorio et al. 2003, p. } \\
325\end{array}$ \\
\hline \multirow{5}{*}{ 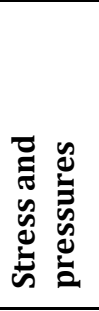 } & Vertical stress & $\mathrm{MPa}$ & 13 & 35 & $10-35$ & $\begin{array}{l}\text { Buryakovsky et al. } \\
2001, \text { p. } 402\end{array}$ \\
\hline & Horizontal stress & $\mathrm{MPa}$ & 8 & 22 & & \multirow{4}{*}{$\begin{array}{l}\text { Buryakovsky et al. } \\
2001, \text { p. } 402 \\
\text { Buryakovsky et al. } \\
2001, \text { p. } 152\end{array}$} \\
\hline & $\begin{array}{l}\text { Hydrostatic } \\
\text { pressure }\end{array}$ & $\mathrm{MPa}$ & 5 & 15 & $4-14$ & \\
\hline & $\begin{array}{l}\text { Pore fluid } \\
\text { pressure }\end{array}$ & $\mathrm{MPa}$ & 6 & 16 & $12-20$ & \\
\hline & Fracture pressure & MPa & 11.57 & 28.41 & & \\
\hline \multirow{3}{*}{ 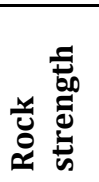 } & Friction angle & o & 19.67 & 26.30 & $21.75-38.09$ & $\begin{array}{l}\text { Kohli \& Zoback 2013, } \\
\text { p. } 5115\end{array}$ \\
\hline & Cohesive strength & $\mathrm{MPa}$ & 3.58 & 4.94 & $0.3-38.4$ & Schön 2011, p. 256 \\
\hline & UCS & $\mathrm{MPa}$ & 8.35 & 16.05 & $7.5-13.9$ & Schön 2011, p. 258 \\
\hline
\end{tabular}


Table 4. Input parameters and calculated minimum and maximum values of $\sigma_{h}$ and $\sigma_{H}$ respectively used to construct the stress polygons shown in Fig. 19. The stress and pressure values have been normalized by the corresponding depth

\begin{tabular}{llllll}
\hline Depth, $\mathbf{m}$ & $\boldsymbol{\sigma}_{\boldsymbol{v}}, \mathrm{MPa} / \mathbf{m}$ & $\boldsymbol{P}_{\boldsymbol{p}}, \mathrm{MPa} / \mathbf{m}$ & $\boldsymbol{\mu}$ & $\boldsymbol{\sigma}_{\boldsymbol{H}}, \mathrm{MPa} / \mathbf{m}$ & $\boldsymbol{\sigma}_{\boldsymbol{h}}, \mathrm{MPa} / \mathbf{m}$ \\
\hline 620 & 0.0235 & 0.0123 & 0.3718 & 0.0356 & 0.0177 \\
2600 & 0.0236 & 0.0174 & 0.5957 & 0.0369 & 0.0194 \\
5000 & 0.0238 & 0.0200 & 0.6445 & 0.0328 & 0.0211 \\
\hline
\end{tabular}

